\title{
Strategie per la valorizzazione di architetture monastiche. Il caso della Badia di Pattano nel Cilento
}

\author{
Antonello Cerbone \\ Saverio D'Auria
}

Abstract

La rigenerazione dei territori rurali è un tema quanto mai attuale che deve passare necessariamente attraverso strategie di valorizzazione, su piccola e larga scala, dei beni culturali in esso ospitati e spesso dimenticati o abbandonati. L'eredità culturale rappresenta una risorsa preziosa frutto delle connessioni, nel corso dei secoli, fra le popolazioni e i luoghi. La via maestra consiste nell'innovazione delle forme di gestione e di divulgazione attraverso le attuali ICT, ponendo come base l'interazione sinergica di diversi ambiti della ricerca.

II presente contributo si inserisce all'interno di una ricerca più ampia sulle architetture monastiche cilentane, sulle loro interrelazioni e ramificazioni in un tessuto generalmente poco incline alla contaminazione. L'attenzione è focalizzata sulla Badia di Santa Maria di Pattano a Vallo della Lucania (SA), testimonianza del monachesimo orientale nel sud d'Italia, architettura bizantina quasi dimenticata che necessita di valorizzazione per mezzo di strategie e di processi basati su approcci multiscalari e di larghe vedute. Attraverso la contestuale lettura critica dei documenti di archivio e dei modelli infografici prodotti da rilievi sistematici, l'obiettivo iniziale è di identificare e datare le più significative trasformazioni subite dal monastero e di comprendere il suo rapporto con il territori.
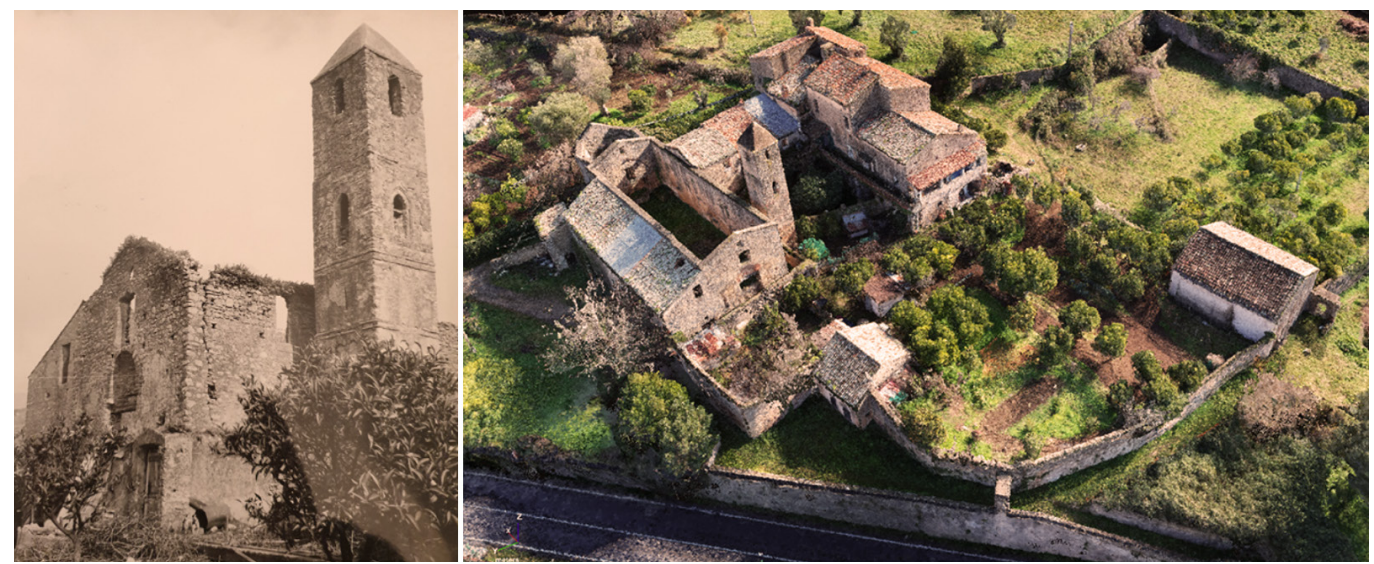


\section{Introduzione}

Tema di attualità nelle strategie di rigenerazione dei territori rurali è la valorizzazione dei beni culturali dimenticati e, troppo spesso, abbandonati. II nostro Paese è ricchissimo di tali testimonianze architettoniche che, purtroppo, mostrano i segni del tempo e dell'incuria, con il rischio di perdere irreversibilmente pezzi di memoria. II Cilento rappresenta una delle tante aree geografiche pregnante di storia che, però, non ha visto nascere strategie condivise e di ampio respiro volte alla disseminazione interdisciplinare e diffusa delle preziose tracce del passato. La storia millenaria del Cilento, infatti, racconta che questo variegato territorio, a larghi tratti impervio, fu crocevia di intensi scambi. Percorsi montuosi di crinale lo mettevano in contatto con le altre civiltà appenniniche (vie della transumanza, luoghi di culto e di mercato), rotte marittime lo avvicinavano alle civiltà nuragiche, egee e mediterranee. II territorio, come noto, fu fortemente interessato da insediamenti protoetruschi, greci e romani.

Esempio di tale 'superficialità culturale' è anche la scarsa - per non dire assente - valorizzazione delle numerose architetture conventuali, la cui esistenza, invece, denuncia chiaramente il trascorso fecondo per il Cilento. I monasteri, infatti, con le loro lunghe e spesso profonde trasformazioni, raffigurano i cambiamenti e le evoluzioni delle comunità religiose che ospitano e, soprattutto, delle dinamiche sociali delle popolazioni limitrofe.

II presente contributo si inserisce all'interno di una ricerca più ampia sulle architetture monastiche cilentane, sulle loro interrelazioni e ramificazioni in un tessuto generalmente poco incline, per vari fattori, alla contaminazione. In particolare, l'interesse di questa ricerca è ricaduto sul territorio di Vallo della Lucania, sede di un importante monastero di origini bizantine: la Badia di Santa Maria di Pattano, uno dei punti di arrivo in cui si insediarono stabilmente i monaci provenienti dalle rotte mediorientali.

L'impostazione metodologica alla ricerca ha contemplato lo studio e l'analisi critica delle informazioni provenienti da fonti bibliografiche e iconografiche che trattano il tema, dei documenti di archivio e dei grafici di rilievo (esistenti e in fase di rielaborazione) al fine di identificare e datare le più significative trasformazioni subite dal monastero nel tempo, di comprendere il suo rapporto con il territorio - in particolare con altre emergenze architettoniche con cui potrebbe essere in qualche modo connesso - e di evidenziare l'importanza del sito riscontrata dai religiosi nella scelta dell'insediamento.

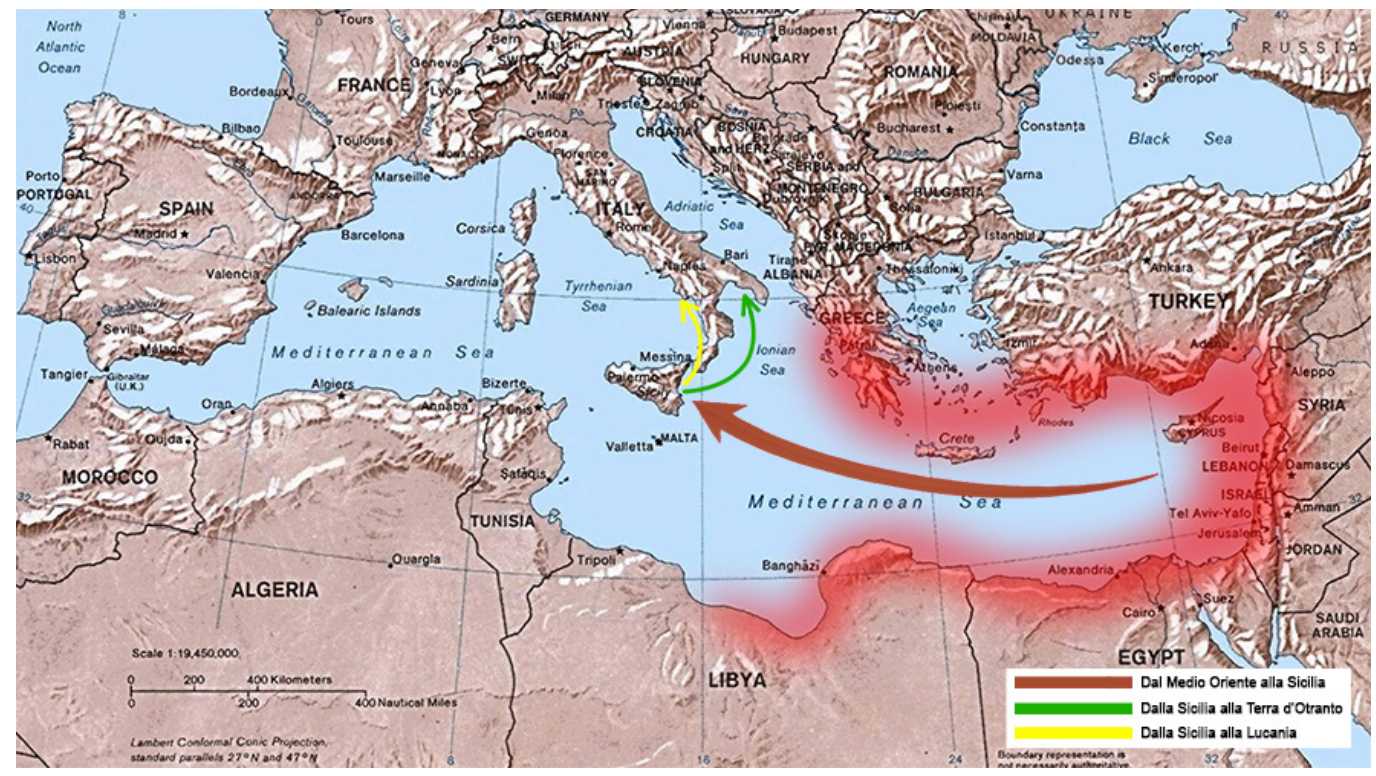




\section{Connessioni tra monachesimo e Cilento}

Nella storia del monachesimo orientale si distinguono due periodi: quello egiziano e quello basiliano. I monaci egiziani vivevano secondo i principi dell'eremitismo e dell'anacoretismo, seguendo le pratiche ascetiche dell'eremita Paolo di Tebe e di Sant'Antonio Abate, vissuti nel III secolo. I monaci basiliani, invece, condividevano i fondamenti di vita dettati nel IV secolo da San Basilio, che riorganizzò radicalmente la vita e la spiritualità monacale secondo il concetto di comunità e di servizio verso gli altri.

In epoca medievale, l'Italia meridionale risentì degli influssi del monachesimo orientale per l'arrivo dei monaci che, a partire dalla fine del VI secolo, furono costretti ad emigrare dalle loro terre d'origine a causa delle invasioni arabe prima e delle persecuzioni iconoclastiche poi, giungendo in Sicilia, in Calabria, in Puglia e in Lucania (fig. I), contaminando la toponomastica, il dialetto, le tradizioni e l'architettura sacra.

I monaci ritrovarono nella cultura e nella civiltà meridionale significative assonanze con le proprie: basti pensare che erano ancora vivi gli usi, i costumi e la lingua della Magna Grecia; anche il territorio, con le sue caratteristiche geo-fisiche e morfologiche, ricordava quello abbandonato in Oriente. Tutto ciò permise la fondazione di comunità religiose che, pur essendo ispirate alla rigida regola dell'ascetismo monastico, diventarono ben presto poli economici e lavorativi, veri e propri punti di riferimento per le popolazioni autoctone [Comes 20।4, p. 9]. Nella fase cenobitica, inoltre, l'influenza dei monaci orientali sulle popolazioni limitrofe era alimentata anche dai complessi manufatti religiosi che erigevano nei luoghi ritenuti più fertili e logisticamente più adatti alle loro attività.

Il fenomeno del monachesimo orientale investì anche il Cilento per diversi fattori positivi, primo fra tutti il naturale isolamento che garantiva il territorio (montuoso, impervio e quasi privo di collegamenti), ideale per la perfezione ascetica a cui aspiravano i religiosi; in secondo luogo per la fertilità delle terre e la presenza di corsi e sorgenti di acqua che permettevano la coltivazione e l'allevamento del bestiame.

A partire dalla fine delVI secolo, quindi, il Cilento registrò una nuova fase di sviluppo socio-economico. Inizialmente protetti nelle zone interne dai longobardi, che vedevano nella loro presenza l'unico elemento concreto per portare avanti il loro programma di dissodamento e coltivazione della terra, e protetti lungo la costa dalla flotta bizantina, i monaci riuscirono a determinare l'effettiva rinascita delle attività sul territorio cilentano [Patrizio 2003, p. 235]. Non sono certe però le vie di connessione che hanno condotto i religiosi nell'entroterra cilentano dalla Calabria, dalla Terra d'Otranto e dalla Sicilia: alcuni autori [I] ipotizzano che i monaci siano sbarcati nell'antico porto diVelia (ubicato a circa 500 metri dalla linea di costa attuale) [De Magistris 1991, pp. 39-44] (fig. 2) e abbiano risalito i fiumi Palistro e Badolato; altri [Cappelli 1957, pp- 231-233; Cerino 1997, pp. 31-36; De Luca 1996, p. I] che siano pervenuti attraverso le vie di Puglia, per chi proveniva dalla Terra d'Otranto, e che abbiamo percorso verso nord la Calabria, per chi proveniva dalla Sicilia, fino ad insediarsi inizialmente sulle montagne del Pollino, per poi inoltrarsi nel Cilento.

Fig. 2. (A) Ricostruzione della linea di costa dell'Eleatide di G. Schmiedt [De Magistris 1991, p. 42] (B) Risalita dei monaci attraverso il percorso fluviale dall'antica linea di costa a Pattano.

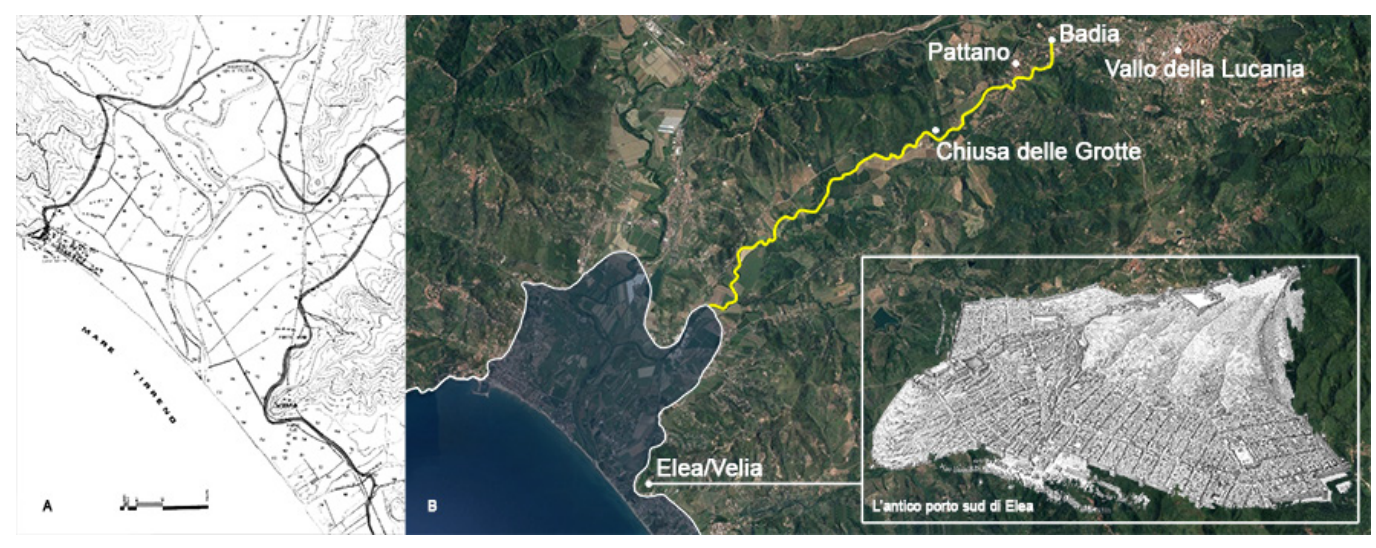


II primo monaco che giunse nei pressi di Pattano fu un eremita che, probabilmente, costituì il suo eremo in una zona prossima a quella della futura fondazione della Badia (a circa 3 chilometri a sud-ovest), chiamata Grotte dei Monaci, oggi conosciuta come Chiusa delle Grotte. Tali denominazioni derivano dalla presenza di tre strutture funerarie a camera, di origine greca, realizzate con blocchi di arenaria messi in opera a secco, del tutto simili a quelli impiegati per la cinta muraria di Elea-Velia.

\section{La Badia e le sue trasformazioni}

II complesso monastico, che occupa una superficie di circa 1.000 metri quadri (fig. 3), sorge a due chilometri a sud-ovest da Vallo della Lucania. Percorrendo la SS I 8 non si percepisce l'integrale conformazione del monastero che, invece, si svela in tutta la sua bellezza una volta giunti nell'antica corte del cenobio, raggiungibile attraverso l'angusto corridoio scoperto e confinato tra la facciata principale della chiesa di Santa Maria e il muro eretto in epoche recenti. Continuando a percorrere la strada sterrata, si raggiunge dapprima il frantoio, attualmente restaurato, e successivamente la cappella di San Filadelfo, oggi restituita al suo antico splendore bizantino.

All'origine, tra I'VIII e la prima metà del X secolo (fig. 4), il monastero era costituito da due vani contigui a piano terra, coperti da volte a crociera e collegati tra loro da un corridoio voltato a botte. Al primo piano, invece, vi erano altri due vani raggiungibili da una scala esterna e da un ballatoio. Dalla via antica, attualmente nota come strada vicinale Badia, si entrava in un piccolo chiostro (fig. 5c) che dava l'accesso alla corte.

Elemento peculiare del complesso monastico (figg. 5a-5g) è la chiesa di Santa Maria (fig. 5e), risalente ad un periodo compreso tra il X e I'XI secolo, a navata unica con abside poligonale e con sviluppo est-ovest, tipico delle chiese bizantine. Lunga circa 25 metri e larga 8, attualmente si presenta priva di copertura che un tempo doveva essere a due spioventi sorretti

Fig. 3. Ortofoto da nuvola di punti.

Fig. 4. Planimetria attuale con individuazione del complesso monastico tra il IX e il XIV secolo, in rosso, e degli ampliamenti successivi al XVI secolo, in blu [fig. or. tratta da Cerino 1997, p. 43].
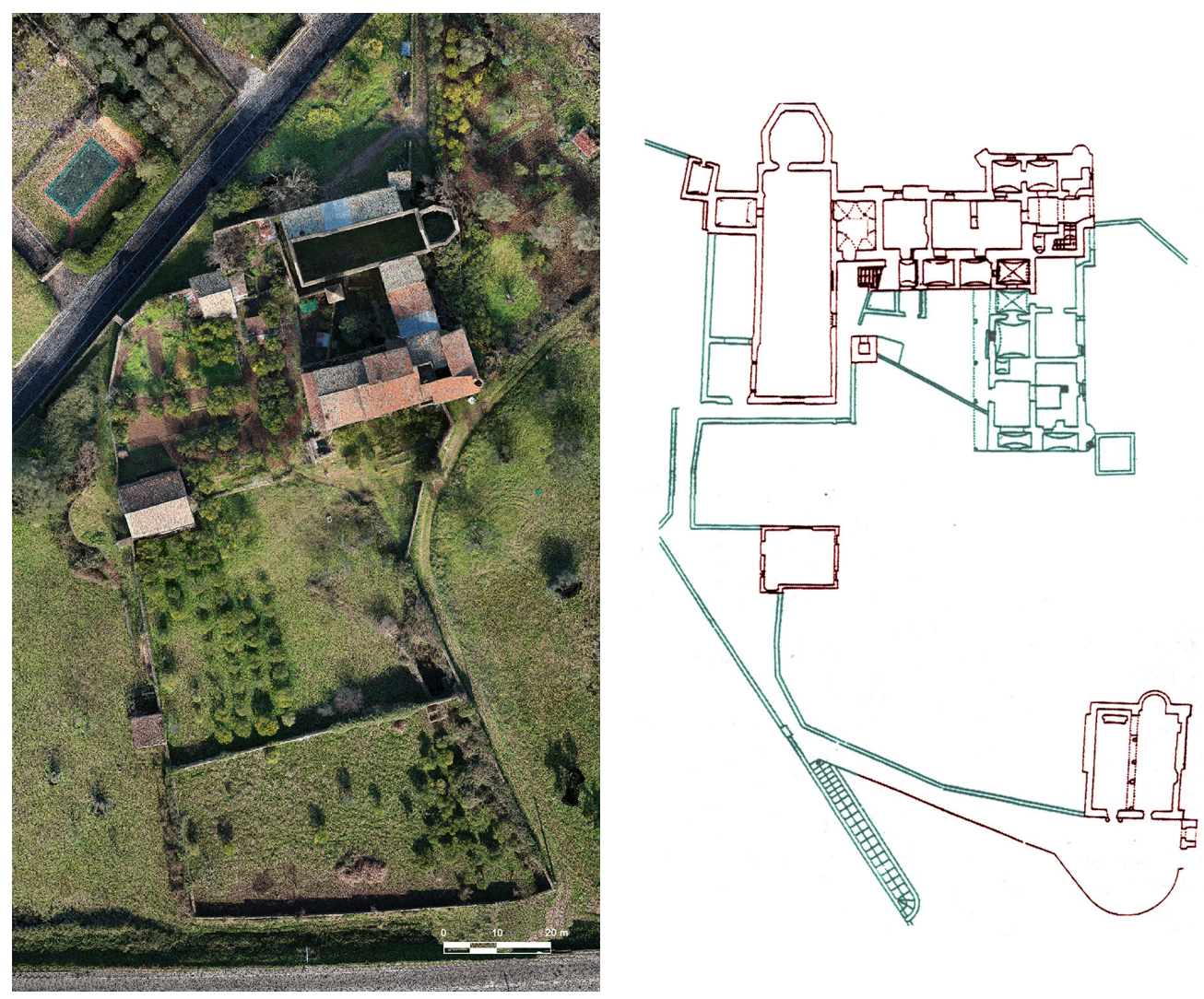
da capriate lignee. Successivamente, in epoca angioina, fu realizzato l'imponente arco trionfale a sesto acuto per collegare la navata all'abside esagonale (fig. 5f), una vola coperta a settori ogivali. La chiesa era costituita anche da due cappelle laterali, quasi ad alludere ad un impianto a croce latina, con ingressi ad archi acuti.

Nella corte del cenobio si eleva, per oltre 15 metri, un campanile a base quadrangolare (fig. 5d) costituito da cinque ordini. A partire dal secondo, la struttura è alleggerita da bifore e monofore, tutte diverse da loro, alcune tamponate e altre disegnate con materiali cromaticamente diversi. Questa torre si ritiene realizzata tra X e XI secolo.

Un'altra preziosa testimonianza dell'arte bizantina presente in questo sito è la cappella dedicata a San Filadelfo (fig. 5b), primo egumeno del monastero di Pattano vissuto tra il IX e il $X$ secolo. II fabbricato, recentemente restaurato, è a pianta rettangolare di circa II metri per 8; si compone di due navate coperte a falde e sorge sui resti di murature di epoca romana, probabilmente appartenenti ad una villa rustica. L'abside, gli intradossi degli archi e alcune parti della parete ad ovest conservano ancora preziosi affreschi di epoca bizantina.

Fig. 5. Fotografie del complesso: (A) Badia di S. Maria di Pattano, vista sud-ovest; (B) Cappella di San Filadelfo, vista dell'interno; (C) Chiostrino, ballatoio al primo piano; (D) Torre campanaria; (E) Chiesa di S. Maria, vista dell'interno; (F) Abside poligonale, vista dell'interno; (G) aerea da drone.

Fig. 6. Piante in sovrapposizione con individuazione delle funzioni e dei period
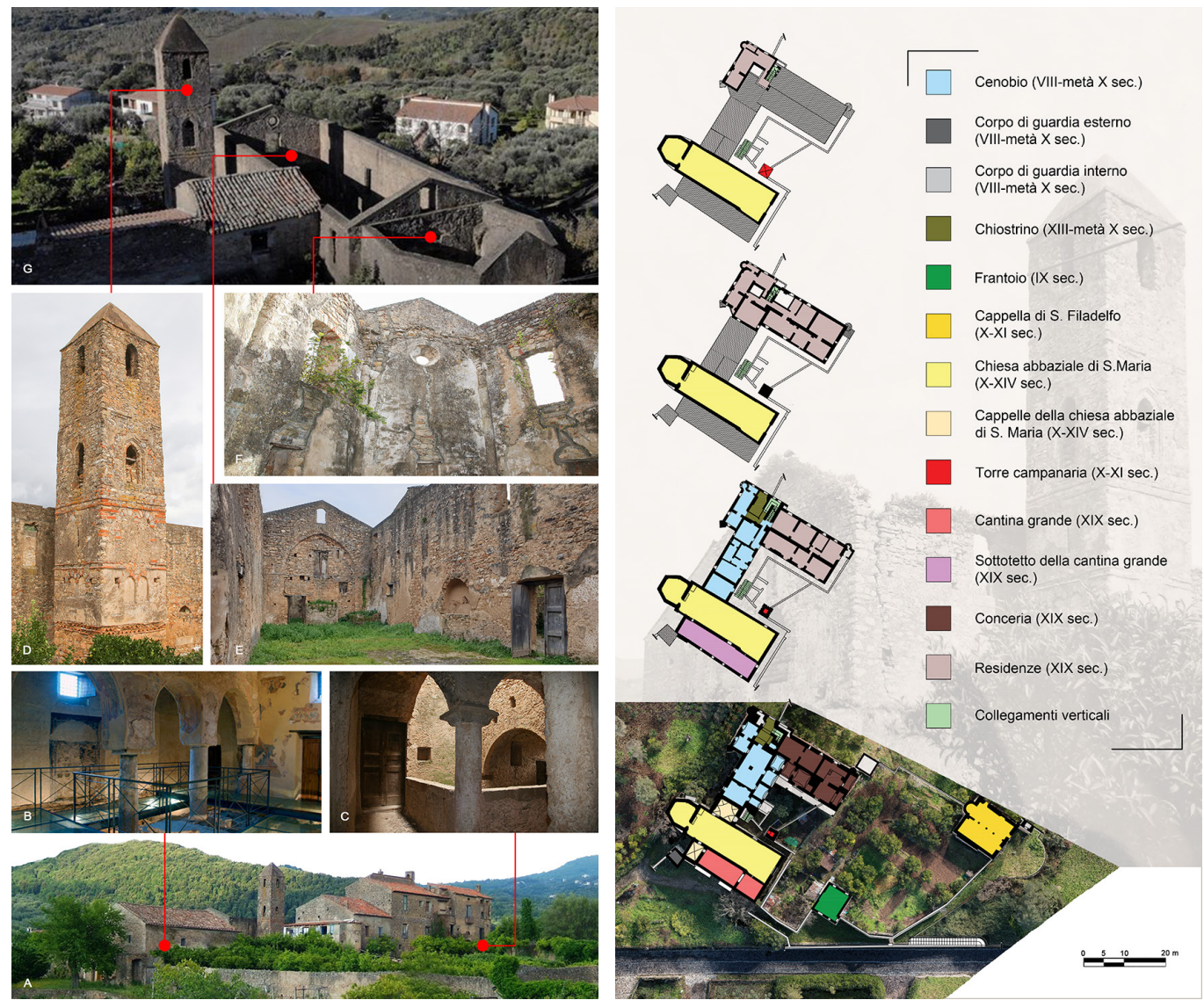

Quando il monastero fu soppresso da Paolo III alla fine del XV secolo, passò "di commenda in commenda sempre più degradandosi"' [Cerino 1997, p. 4I]. Nel corso dei secoli, infatti, all'originaria struttura, furono aggiunti diversi volumi funzionali alle esigenze dei nuovi conduttori. Ne sono alcuni esempi il lungo corpo di fabbrica addossato al lato sinistro della chiesa ed il fabbricato adibito a laboratorio per la concia delle pelli e ad abitazione eretto perpendicolarmente al nucleo originario del cenobio (fig. 6).

La difficoltà di datare con precisione i vari manufatti e di definirne le funzioni che nei secoli si sono succedute è confermata da diversi autori [2]. 


\section{La conoscenza del sito attraverso il rilievo}

II complesso monastico di Pattano, nonostante la sua non trascurabile importanza da un punto di vista culturale e architettonico, non è sufficientemente documentato da grafici di rilievo editi. Gli unici elaborati che rappresentano, in scala opportuna e con varie viste, la complessità del manufatto risalgono a circa cinquant'anni fa e sono conservati presso l'archivio storico della Soprintendenza Archeologica, belle arti e paesaggio per le province di Salerno ed Avellino [3] (fig. 7).

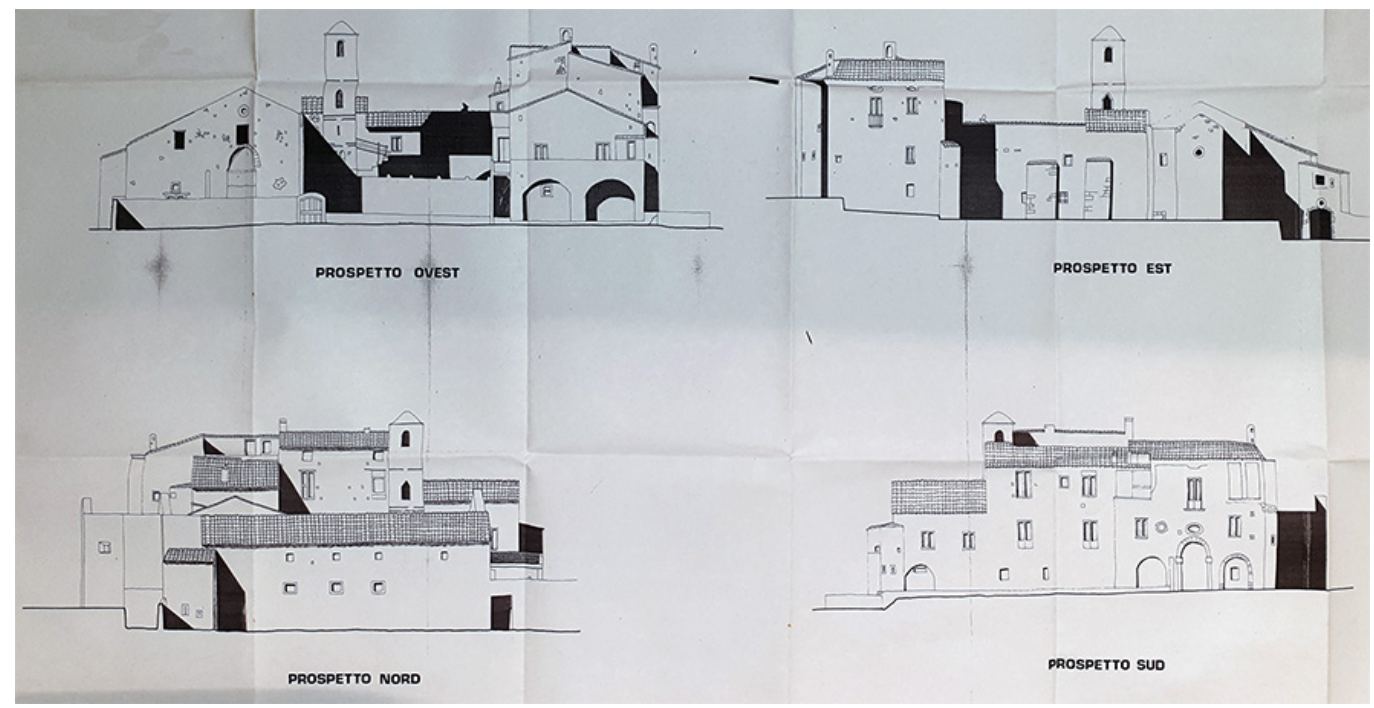

Il contributo sintetizza la ricerca in corso volta a rilevare la Badia e il suo contesto in maniera sistematica e per mezzo delle attuali tecnologie di digitalizzazione tridimensionale e colorimetrica, per varie ragioni: analizzare i rapporti volumetrici che intercorrono tra i vari manufatti; datare in maniera coerente, grazie anche alla lettura puntuale dei paramenti murari, le fasi costruttive che hanno interessato il monastero; virtualizzare le architetture per scopi di disseminazione scientifica e di valorizzazione culturale; aggiornare e divulgare i rilievi, con particolare attenzione ai dettagli e ai decori superstiti; individuare aspetti tipologici comuni ai tanti monasteri cilentani coevi al fine di redigere un atlante delle tecniche costruttive monastiche del territorio.

Dato lo stato in cui versano molti degli ambienti della Badia, ad oggi non è possibile eseguire un rilievo in-door in sicurezza. Prima che vengano effettuate puntuali e non troppo invasive operazioni di manutenzione e di minimizzazione del rischio crollo (alcuni solai e coperture andrebbero puntellati e diversi blocchi in pietra ricollocati), è stato progettato un rilievo fotogrammetrico aereo mediante l'impiego di un drone DJI Spark, allo scopo di realizzare un modello tridimensionale per le prime indagini morfometriche sul complesso.

I piani di volo sono stati progettati tenendo in considerazione il GSD atteso (almeno 2 $\mathrm{mm} /$ pix per rappresentazioni valide alla scala 1:50), le caratteristiche tecniche del sensore fotografico ( 12 MPx con sensore CMOS da 1/2.3") e la sovrapposizione voluta tra prese consecutive (almeno il 70\%) e sono stati pianificati da remoto su una piattaforma web [4] automaticamente connessa all'applicativo software di gestione del volo in situ. Come si può vedere in figura 8 , sono state programmate sei strisciate: due a quota 30 metri sull'intero lotto con camera nadirale (inclinata a $85^{\circ}$ rispetto all'orizzonte) e con direzioni ortogonali nord-sud ed est-ovest; quattro a quota 20 metri sulla sola zona edificata, alternativamente con camera nadirale e obliqua (a circa $45^{\circ}$ ) e con direzioni ortogonali (fig. 9). 


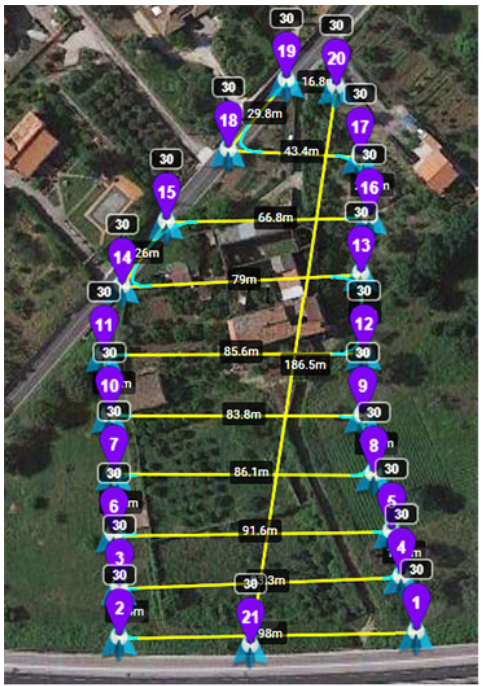

$$
\begin{aligned}
& \text { Settings } \\
& \begin{array}{|l|l|}
\hline \text { Metric } & \text { Imperial } \\
\hline
\end{array}
\end{aligned}
$$

Cruising Speed

Max Flight Speed

Photo Capture Interval

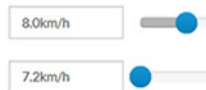

Default Curve Size

Default Gimbal Pitch Mode

Show Discover Missions
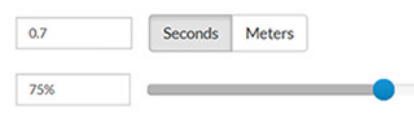

\begin{tabular}{|l|l|l|}
\hline Disabled & Focus POI & Interpolate \\
\hline
\end{tabular}

Use Online Elevation

$$
\square
$$

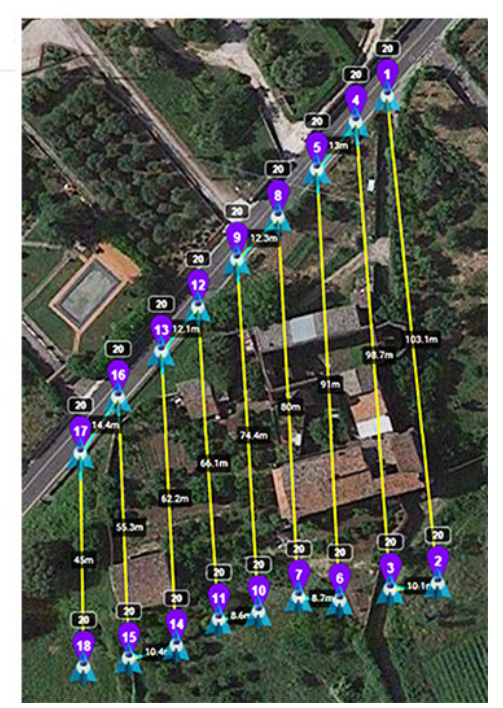

Fig. 9. Tabella riassuntiva del rilievo aerofotogrammetrico.

\begin{tabular}{|c|c|c|c|c|c|c|c|c|}
\hline VOLO & $\begin{array}{c}\text { TRAGITTO } \\
(\mathbf{m})\end{array}$ & $\begin{array}{c}\text { VELOCITÀ } \\
(\mathbf{K m} / \mathbf{h})\end{array}$ & $\begin{array}{c}\text { DURATA } \\
(\mathbf{m} \mathbf{i n} .)\end{array}$ & $\begin{array}{c}\text { QUOTA } \\
(\mathbf{m})\end{array}$ & DIREZIONE & $\begin{array}{c}\text { N. } \\
\text { STRISCIATE }\end{array}$ & $\begin{array}{c}\text { N. } \\
\text { SCATTI }\end{array}$ & $\begin{array}{c}\text { INCLINAZIONE } \\
\text { CAMERA }\end{array}$ \\
\hline 1 & 890 & 8 & 9 & 20 & est-ovest & 12 & 258 & $45^{\circ}$ \\
\hline 2 & 765 & 8 & 8 & 20 & nord-sud & 9 & 265 & $45^{\circ}$ \\
\hline 3 & 1125 & 10 & 9 & 30 & est-ovest & 10 & 169 & $85^{\circ}$ \\
\hline 4 & 610 & 7 & 7 & 20 & est-ovest & 10 & 249 & $45^{\circ}$ \\
\hline 5 & 576 & 6 & 8 & 20 & nord-sud & 10 & 306 & $42^{\circ}$ \\
\hline 6 & 1173 & 10 & 10 & 30 & nord-sud & 7 & 299 & $85^{\circ}$ \\
\hline
\end{tabular}




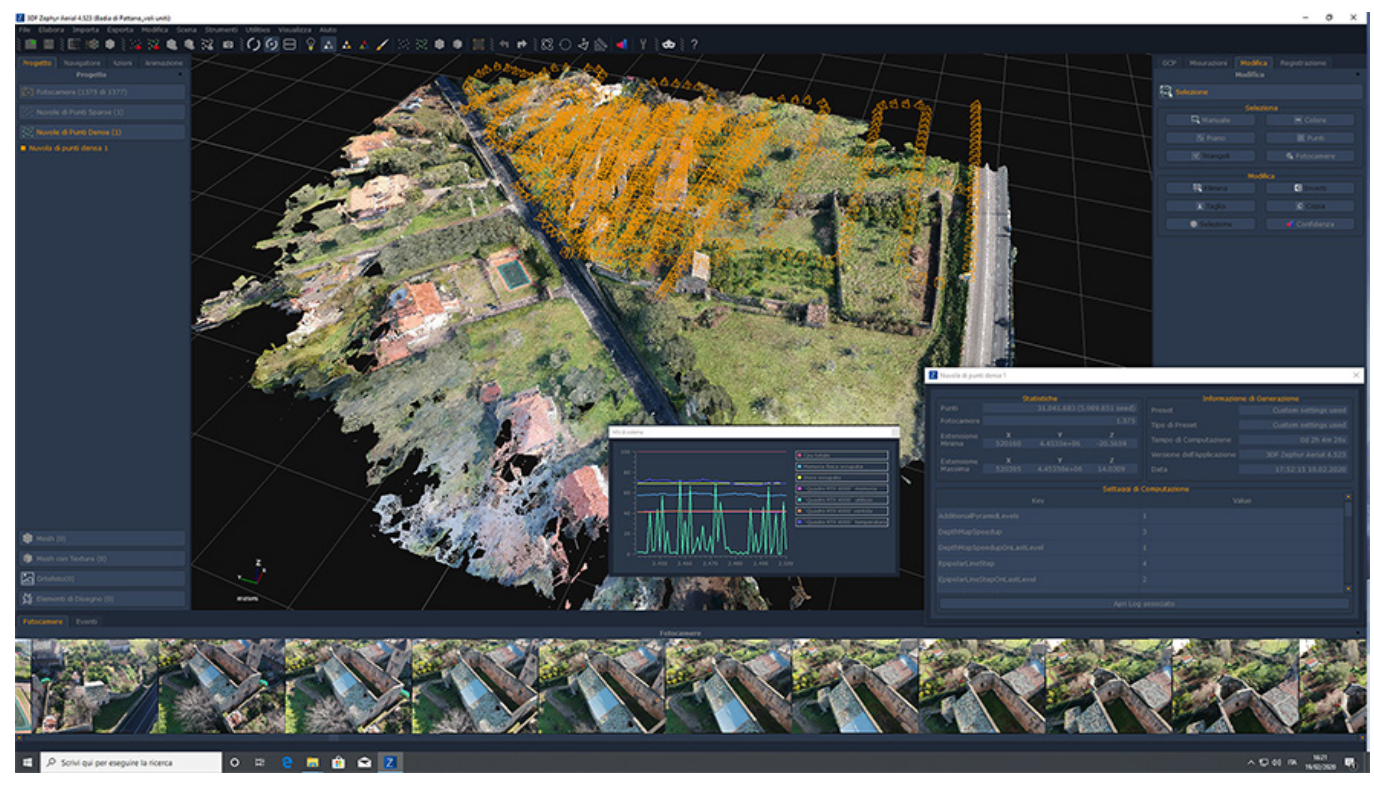

I dati acquisiti ( 375 fotogrammi con altrettanti dati GPS) sono stati successivamente processati attraverso un affidabile software di fotomodellazione [5] che è riuscito ad allineare correttamente e in tempi assolutamente accettabili (2 ore e 4 minuti) tutte le prese, georeferendo e scalando il modello a nuvola di punti (circa 3 I milioni di punti) con le coordinate acquisite dal sensore del drone (fig. I0). Quest'ultimo, sebbene non possa essere assolutamente affidabile come un ricevitore GPS professionale, ha comunque restituito informazioni ritenute sufficienti per gli scopi di questo rilievo.

II modello così ottenuto costituisce la base di dati per le future elaborazioni grafiche e andrà integrato con le nuvole da laser-scanning e con le battute da stazione totale (fig. I I).

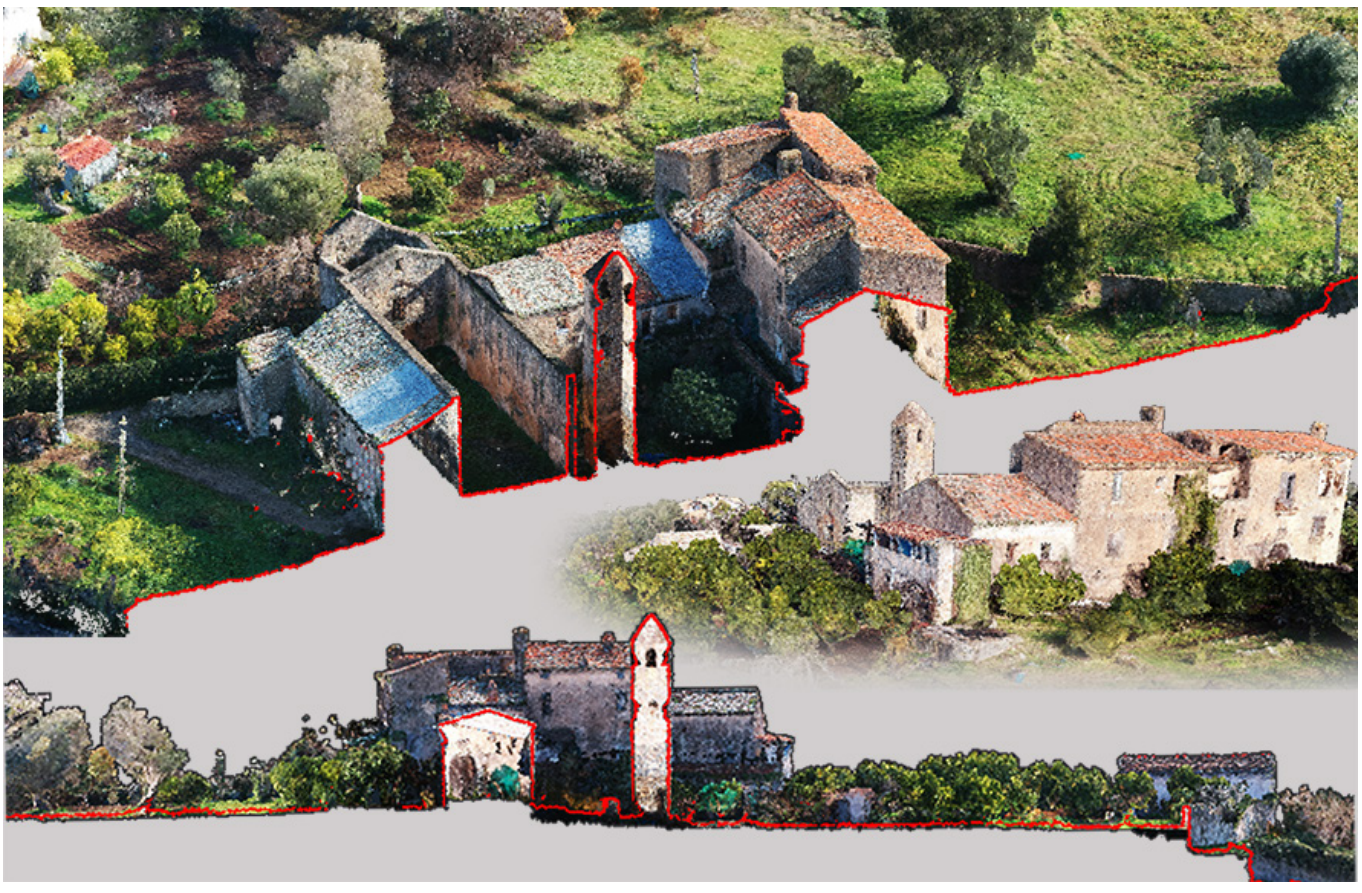




\section{Conclusioni}

La ricerca, seppur in fase iniziale di svolgimento, ha messo in evidenza quanto sia fondamentale e produttivo l'approccio interdisciplinare ad un tema. La Badia di Pattano rappresenta solo uno degli innumerevoli casi di preziosissima testimonianza storico-culturale dimenticata e che necessita di valorizzazione per mezzo di approcci multiscalari e di larghe vedute.

È in fase di programmazione il rilievo interno dei manufatti che compongono il complesso monastico e la successiva rappresentazione. Infatti, per definire nuove, reali e concrete strategie di valorizzazione del patrimonio in esame, è fondamentale partire da una loro affidabile ed esaustiva descrizione morfo-metrica, atta ad implementare le informazioni in sistemi informativi che garantiscono l'interazione e la fruibilità a diversi livelli. Inoltre, attraverso la contestuale lettura critica dei documenti di archivio e dei modelli info-grafici prodotti (nuvole di punti, ortofoto ad alta risoluzione dei paramenti murari, piante, sezioni e prospetti, dettagli architettonici) sarà possibile definire una più attendibile cronologia delle strutture per far luce sulla storia della Badia e del suo rapporto con il contesto (fig. I2).

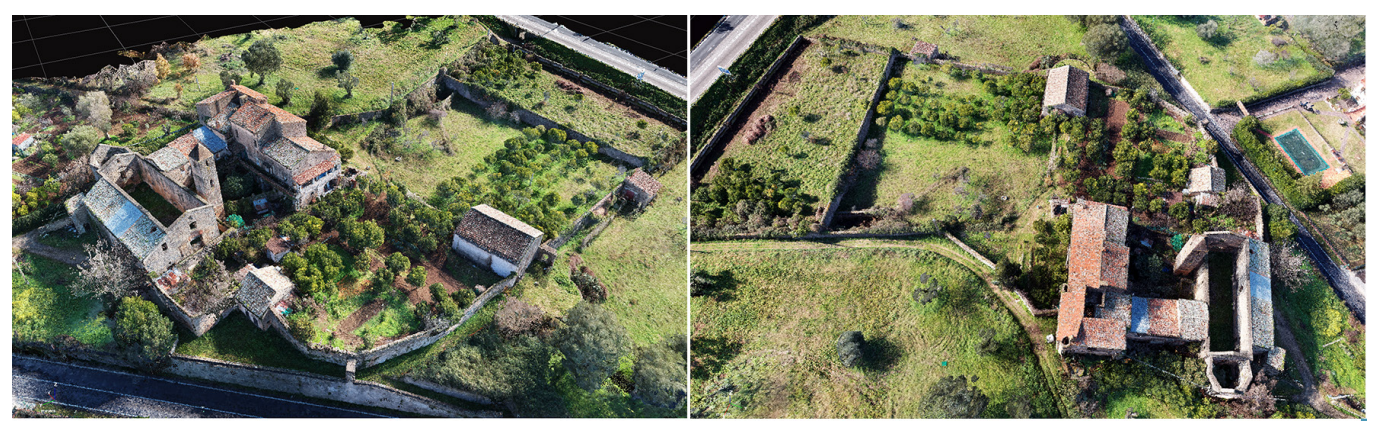

\section{Ringraziamenti}

Gli Autori desiderano ringraziare la Dott.ssa Lara Giulio, consigliere del Comune di Vallo della Lucania con deleghe alle Politiche per la valorizzazione e riqualificazione del patrimonio artistico e culturale e alle Politiche scolastiche, educative e per il diritto allo studio, e la Dott.ssa Elvira Cantarella, funzionario amministrativo dell'Ufficio Tutela della Soprintendenza Archeologica, Belle Arti e Paesaggio per le Province di Salerno e Avellino.

\section{Note}

[I] Sull'argomento si veda: Ebner 1979.

[2] De Giorgi ( 1 882), in merito alla chiesa di Santa Maria, scrive che "freschi del XVII secolo sovrapposti ad altri molto antichi di stile greco barbaramente mutilati per le nuove costruzioni addossate alle antiche". Ancora, Ebner (1967) afferma che "allo stato è impossibile stabilire se la chiesa abbaziale venne rifatta (seconda metà del XIII-prima del XIV sec.) sulla primitiva o se questa deve essere vista in quella di S. Filadelfo".

[3] I grafici sono relativi a Rilievo del monumento prima dell'intervento di ricostruzione e restauro. Chiesa di S. Filadelfo (f. F3-95I); Progetto di restauro della chiesa di S. Filadelfo, progettista prof. arch. Arnaldo Venditti, 1990 (f. F3-954); Progetto esecutivo. Recupero complesso abbaziale Santa Maria di Pattano e prediagnosi e condizioni di degrado, progettisti architetti Gerardo Del Gaudio, Antonio Gambardella, Franco Luongo, Domenico Nicoletti, 1993 (f. F3-954): Progetto di restauro Badia di Pattano. Restauro del campanile, progettista prof. arch. Arnaldo Venditti, 1994 (f. F3-996); Intervento di consolidamento e restauro per la valorizzazione del complesso monumentale S. Maria de Pactano, progettisti vari, 2004 (f. F3- I 365); Restauro del complesso monumentale di S. Maria di Pattano (Vallo della Lucania - SA), progettista arch. Francesco Mautone (f. Z).

[4] www.flylitchi.com

[5] 3DF Zephyr Aerial, versione 4.523 


\section{Riferimenti bibliografici}

Cappelli Biagio (1957). Le chiese rupestri del materano. In Archivio storico per la Calabria e la Lucania, vol. 26, pp. 223-289.

Cerino Vincenzo (1997). La Badia di S. Maria di Pattano. Napoli: Zincografia Partenopea.

Comes Federica (20 I4). L'Architettura eremitica in Costiera Amalfitana. Specificità e problemi di conservazione. Tesi di Dottorato in Storia e conservazione dei beni architettonici e del paesaggio (XXVI Ciclo) Presso l'Università degli Studi di Napoli Federico II. Napoli.

De Giorgi Cosimo (20 I6). Viaggio nel Cilento. Casalvelino: Galzerano Editore. (Ed. orig. De Giorgi Cosimo (I 882). Da Salerno al Cilento. Firenze:Tipografia Galileiana).

De Luca Gaetano ( 1996). La badia di S. Maria di Pattano. In Natura e Montagna. Bologna: Pàtron Editore, vol. XLIII, pp. I-6.

De Magistris Ettore (199|). Problemi di Topografia del Litorale Velino. In Fra le Coste di Amalfi e Velia. Contributi di Storia antica e Archeologia. Napoli. Arte Tipografica, vol. 8, pp. 39-8I.

Ebner Pietro (1967). Monasteri bizantini nel Cilento. S. Maria di Pattano. In Rassegna storica Salernitana. Salerno: Società Salernitana di Storia Patria, 1968-1983, XXIX-XLIII. pp. I75-250.

Ebner Pietro (1979). Economia e società del Cilento medioevale. Roma: Edizioni di Storia e Letteratura.

Minucci Eleonora (2018). APR e droni nella moderna ricerca archeologica: un primo approccio. In Newsletter di Archeologia CISA, 9/2018, pp. $91-114$

Patrizio Salvatore (2003). Breve profilo storico del Cilento. In Rosi Massimo, Jannuzzi Ferdinando (a cura di). Le coste Napoletane Napoli: Officine Grafiche, pp. 233-248.

Repola Leopoldo, Giordano Andrea (2016). The double dynamics of knowledge: reality and virtual reality in the enhancement project of Torre Maggiore of Villa Rufolo, Ravello. In DisegnareCon, 17, 9, pp. I2. I - I2.9.

Venditti Arnaldo (1967). Architettura bizantina nell'Italia meridionale. Napoli: L'arte tipografica, vol. I-II.

Verhoeven Geert (2016). Basics of photography for cultural heritage imaging. In Stylianidis Efstratios, Remondino Fabio (eds.) 3D Recording, Documentation and Management of Cultural Heritage. Dunbeath Mill:Whittles Publishing.

\section{Autori}

Antonello Cerbone, Università degli Studi di Napoli Federico II, antonello.cerbone@unina.it

Saverio D'Auria, Università degli Studi di Napoli Federico II, saverio.dauria@unina.it

Per citare questo capitolo: Cerbone Antonello, D'Auria Saverio (2020). Strategie per la valorizzazione di architetture monastiche. II caso della Badia di Pattano nel Cilento/The apulian pavilion at the Rome Exposition. Geographic and temporal connections in an ephemeral architecture. In Arena A., Arena M., Brandolino R.G., Colistra D., Ginex G., Mediati D., Nucifora S., Raffa P. (a cura di). Connettere. Un disegno per annodare e tessere Atti del $42^{\circ}$ Convegno Internazionale dei Docenti delle Discipline della Rappresentazione/Connecting. Drawing for weaving relationships. Proceedings of the 42th International Conference of Representation Disciplines Teachers. Milano: FrancoAngeli, pp. 1938-1957. 


\title{
Strategies for the Valorisation of Monastic Architectures. The Case of the Badia of Pattano in Cilento
}

\author{
Antonello Cerbone \\ Saverio D'Auria
}

\section{Abstract}

The regeneration of rural areas is a current issue that needs valorization strategies, on a small and large scale, of the cultural heritage hosted in it and often forgotten or abandoned. Cultural heritage represents a precious resource, the result of interaction and connections over the centuries between populations and places. The main route consists in the innovation of the forms of management and dissemination through the current ITC, placing as a basis the synergy interaction of different fields of research. This paper is part of a wider research on Cilento's monastic architectures, on their interrelationships and ramifications in a fabric generally not prone to contamination. The attention is focused on the Badia of Santa Maria of Pattano in Vallo della Lucania (SA), testimony of eastern monasticism in southern Italy, an almost forgotten Byzantine architecture that needs enhancement by means of strategies and processes based on multiscalar approaches and open minded.

Through the contextual critical reading of the archive documents and the infographic models produced by systematic surveys, the initial objective is to identify and date the most significant transformations of the monastery, to understand its relationship with the territory.
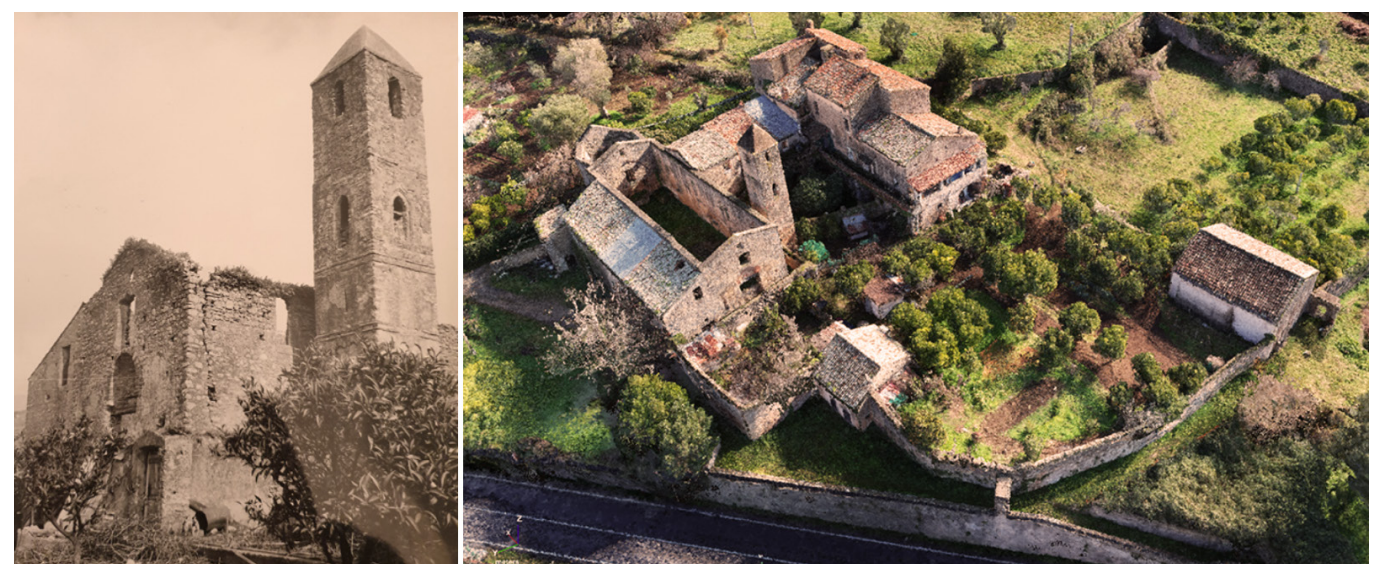


\section{Introduction}

A topical issue in strategies for the regeneration of rural areas is the enhancement of forgotten and, all too often, abandoned cultural heritage. Our country is very rich in such architectural testimonies which, unfortunately, show the signs of time and neglect, with the risk of irreversibly losing pieces of memory. Cilento represents one of the many geographical areas pregnant with history that, however, has not seen the birth of shared and wide-ranging strategies aimed at the interdisciplinary and widespread dissemination of the precious traces of the past. The thousand-year-old history of Cilento, in fact, tells us that this varied territory, at wide stretches impervious, was a crossroads of intense exchanges. Mountain ridge routes put it in contact with the other Apennine civilizations (transhumance routes, places of worship and markets), maritime routes brought it closer to the Nuragic, Aegean and Mediterranean civilizations. The territory, as known, was strongly affected by proto-Etruscan, Greek and roman settlements.

An example of this cultural superficiality is also the scarce -if not absent- valorisation of the numerous convent architectures, whose existence, instead, clearly denounces the fertile past of Cilento.The monasteries, in fact, with their long and often profound transformations, depict the changes and evolutions of the religious communities they host and, above all, the social dynamics of the neighbouring populations.

This contribution is part of a wider research on Cilento's monastic architectures, their interrelationships and ramifications in a fabric generally not very prone, for various factors, to contamination. In particular, the focus of this research is on the territory of Vallo della Lucania, seat of an important monastery of Byzantine origins: the Badia of Santa Maria of Pattano, one of the arrival points where monks from the Middle Eastern routed settled permanently. The methodological approach to the research has contemplated the study and critical analysis of information from bibliographic and iconographic sources that deal with the theme, archival documents and relevant graphs (existing and undergoing review) in order to identify and date the most significant transformations suffered by the monastery over time, to understand its relationship with the territory -in particular with other architectural emergencies with which it might be in some way connected- and to highlight the importance of the site detected by the religious in the choice of the settlement.

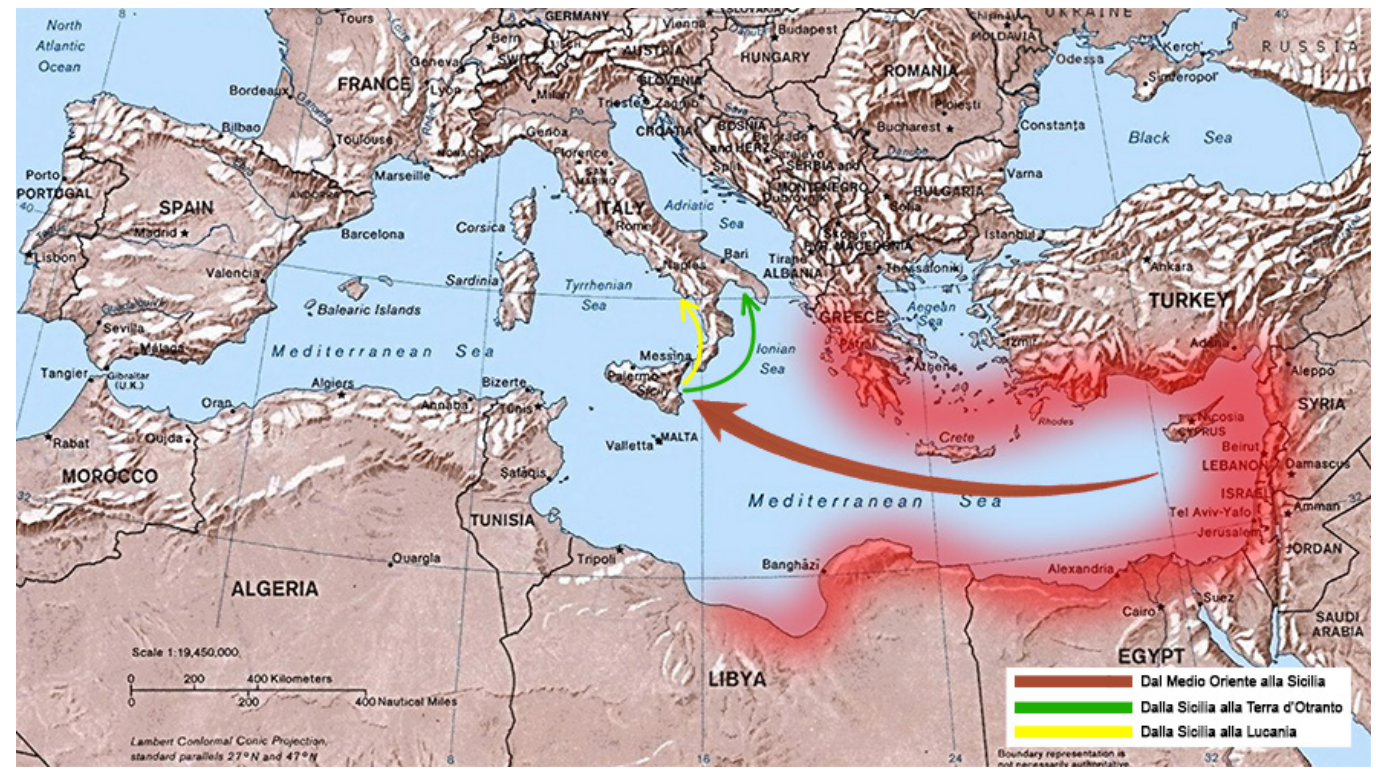




\section{Connections between monasticism and Cilento}

In the history of Eastern monasticism there are two periods: Egyptian and Basilian. Egyptian monks lived according to the principles of hermitry and anchoritism, following the ascetic practices of the hermit Paul of Thebes and Saint Anthony Abbot, who lived in the 3rd century. The Basilian monks, on the other hand, shared the foundations of life dictated in the 4th century by Saint Basil, who radically reorganized monastic life and spirituality according to the concept of community and service to others.

In medieval times, southern Italy was affected by the influences of eastern monasticism due to the arrival of monks who, starting from the end of the 6th century, were forced to emigrate from their lands of origin due to the Arab invasions first and then to iconoclastic persecutions, arriving in Sicily, Calabria, Apulia and Lucania (fig. I), contaminating toponymy, dialect, traditions and sacred architecture.

The monks found in the southern culture and civilization significant similarities with their own: suffice it to say that the customs and language of Magna Graecia were still alive; even the territory, with its geo-physical and morphological characteristics, was reminiscent of the one abandoned in the East. All this allowed the foundation of religious communities which, although inspired by the rigid rule of monastic asceticism, soon became economic and working centres, real points of reference for the native populations [Comes 20 I4, p. 9]. In the cenobitic phase, moreover, the influence of the eastern monks on the neighbouring populations was also fueled by the complex religious artefacts they erected in the places considered most fertile and logistically most suitable for their activities.

The phenomenon of eastern monasticism also affected Cilento for several positive factors, first of all the natural isolation that the territory guaranteed (mountainous, impervious and almost unconnected): ideal for the ascetic perfection to which the religious aspired; secondly for the fertility of the land and the presence of streams and springs of water that allowed cultivation and cattle breeding.

From the end of the sixth century, therefore, the Cilento recorded a new phase of socio-economic development. Initially protected in the inland areas by the Lombards, who saw in their presence the only concrete element to carry on their programme of tillage and cultivation of the land, and protected along the coast by the Byzantine fleet, the monks succeeded in determining the effective rebirth of activities in the Cilento territory [Patrizio 2003, p. 235].

However, the connection routes that led the religious to the Cilento hinterland from Calabria,Terra d'Otranto and Sicily are not certain: some authors [I] hypothesize that the mon$\mathrm{ks}$ landed in the ancient port of Velia (located about 500 meters from the current coastline) [De Magistris 199I, pp. 39-44] (fig. 2) and went up the rivers Palistro and Badolato; others [Cappelli 1957, pp. 231-233; Cerino 1997, pp. 31-36; De Luca 1996, p. I] that they came through the streets of Apulia, for those arriving from Terra d'Otranto, and that they travelled northwards through Calabria, for those arriving from Sicily, until they initially settled in the mountains of Pollino, and then went into Cilento.

Fig. 2. (A) Reconstruction of the Eleatide coast line by G. Schmiedt [D Magistris 1991, p. 42]; (B) Ascent of the monks through the river from the ancient coast line to Pattano.

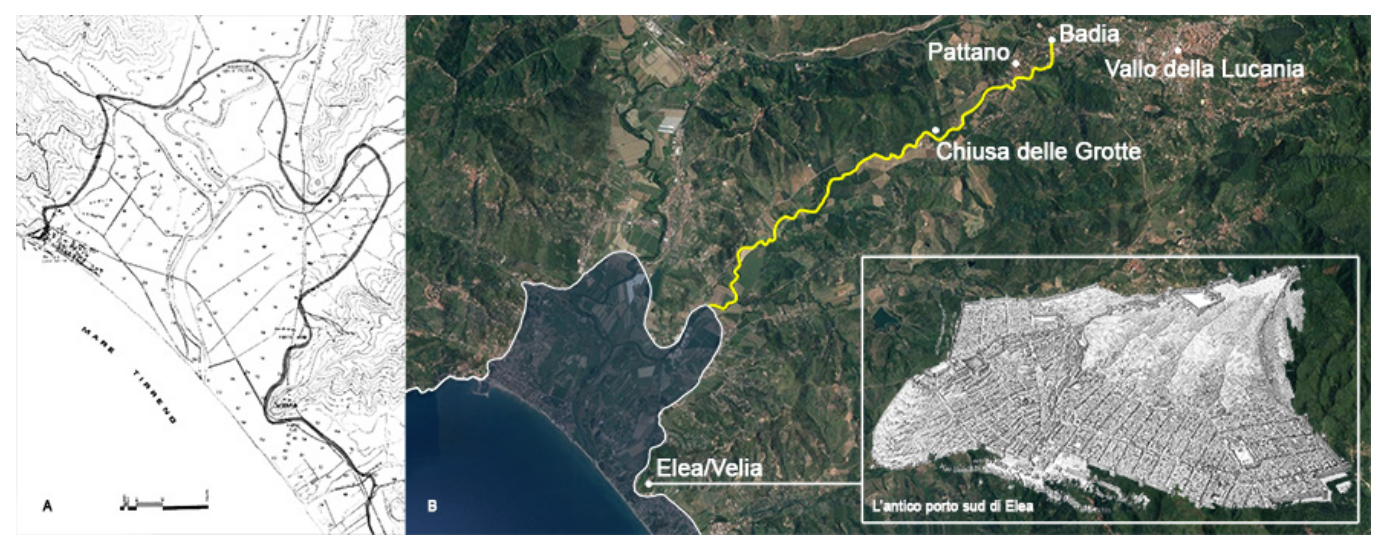


The first monk who arrived near Pattano was a hermit who probably built his hermitage in an area close to that of the future foundation of the Badia (about $3 \mathrm{~km}$ south-west), called Grotte dei Monaci, now known as Chiusa delle Grotte. These names derive from the presence of three chamber funerary structures, of Greek origin, made of dry sandstone blocks, very similar to those used for the walls of Elea-Velia.

\section{The Badia and its transformations}

The monastic complex, which occupies an area of about 1,000 square meters (fig. 3), is located two kilometers southwest of Vallo della Lucania. If you drive along the ss 18 you will not perceive the complete conformation of the monastery which, instead, reveals itself in all its beauty once you arrive to its ancient court, reachable through the narrow open and confined corridor between the main facade of the church of Santa Maria and the wall erected in recent times. Continuing along the dirt road, you first reach the oil mill, now renewed, and then the chapel of San Filadelfo, now restored to its ancient Byzantine splendour.

Originally, between the 8th and the first half of the I0th century (fig. 4), the monastery consisted of two adjoining rooms on the ground floor, covered by cross vaults and connected by a barrel-vaulted corridor. On the first floor, instead, there were two other rooms accessible by an external staircase and a gallery. From the ancient street, now known as the Badia vicinal road, one entered a small cloister (fig. $5 \mathrm{c}$ ) that gave access to the courtyard.

A peculiar element of the monastic complex (figs. $5 a-5 g$ ) is the church of Santa Maria (fig. $5 e$ ), dating back to a period between the IOth and I Ith century, with a single nave with polygonal apse and east-west development, typical of Byzantine churches. It is about 25 metres long and 8 metres wide and currently has no roof, which once had to be composed by two slopes supported by wooden trusses. Later, in the Angevin era, the imposing triumphal pointed arch was built to connect the nave to the hexagonal apse (fig. 5f), a flywheel

Fig. 3. Ortophoto from point clouds.

Fig. 4. Current plan with identification of the monastic complex between the $I X$ and $X I V$ century, in red, and of the extensions after the $\mathrm{XVI}$ century, in blue [or. fig. taken from Cerino 1997, p. 43].
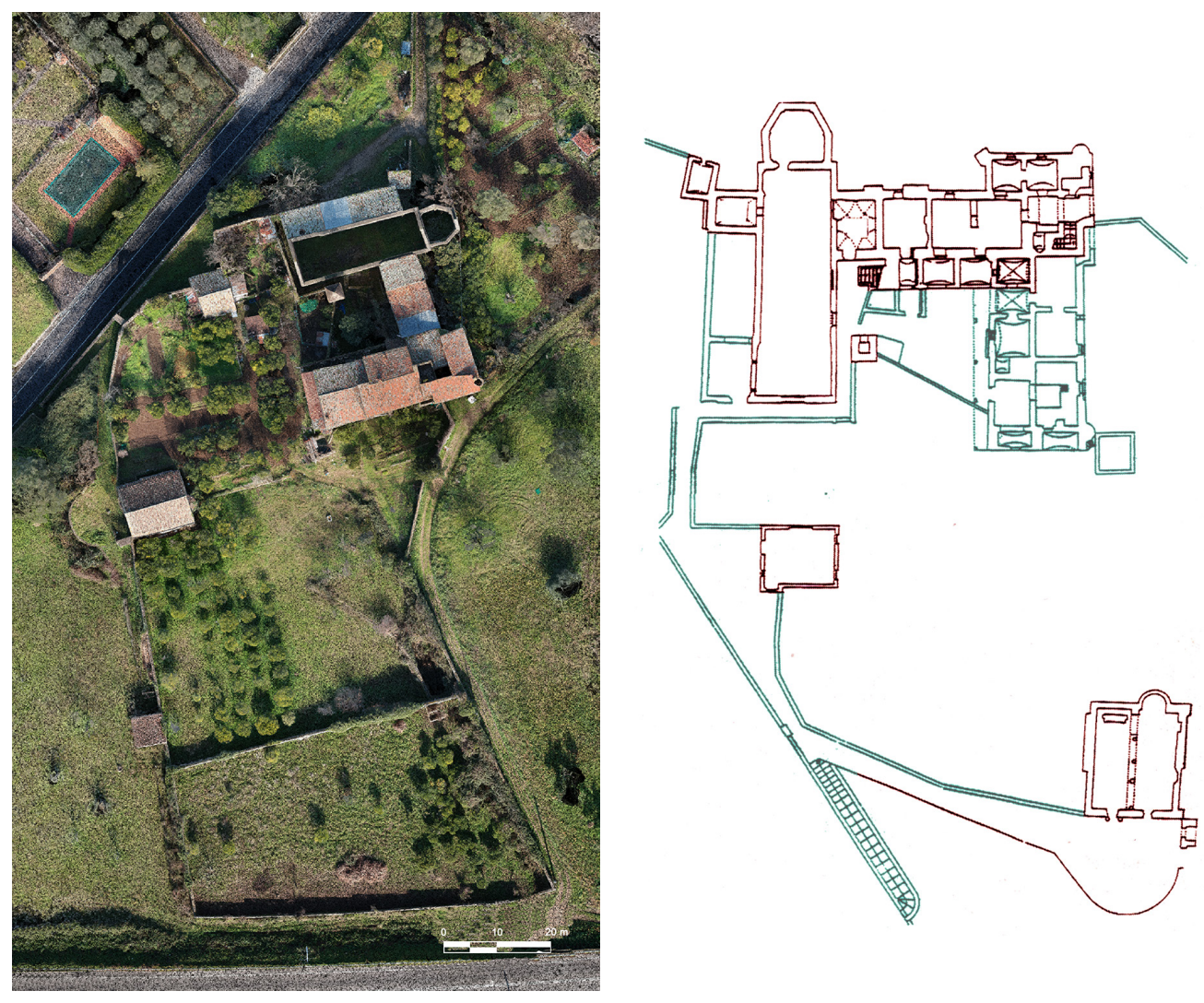
covered with ogival sectors. The church also consisted of two side chapels, almost alluding to a Latin cross plan, with entrances with pointed arches.

In the courtyard of the coenoby stands, for over 15 meters, a quadrangular bell tower (fig. $5 d)$ made up of five orders. Starting from the second, the structure is lightened by mullioned windows and single lancet windows, all different from each other, some of which are buffered and others designed with chromatically different materials. This tower is believed to have been built between the I0th and I Ith centuries.

Another precious testimony of Byzantine art on this site is the chapel dedicated to Saint Philadelphus (fig. 5b), the first hegumen of the monastery of Pattano who lived between the 9th and I0th centuries. The building, recently restored, has a rectangular plan of about II meters by 8 meters; it consists of two aisles covered in pitches and it stands on the remains of Roman walls, probably belonging to a rustic villa. The apse, the intradoses of the arches and some parts of the west wall still preserve precious frescoes from the Byzantine period. When the monastery was suppressed by Paul III at the end of the I5th century, it went

Fig. 5. Photographs of the complex: (A) Badia of S. Maria of Pattano, south-west view: $(\mathrm{B})$ Chapel of San Filadelfo view of the interior: (C) Cloister balcony on (C) first floor: (D) Bell tow (E) Chur, of S.Maria, (E) Church of S. Maria view of the interior; (F) Polygonal apse, view of the interior. (G) Cenobium and Church aerial view from drone.

Fig. 6. Overlapping plants with identification of functions and historical periods.
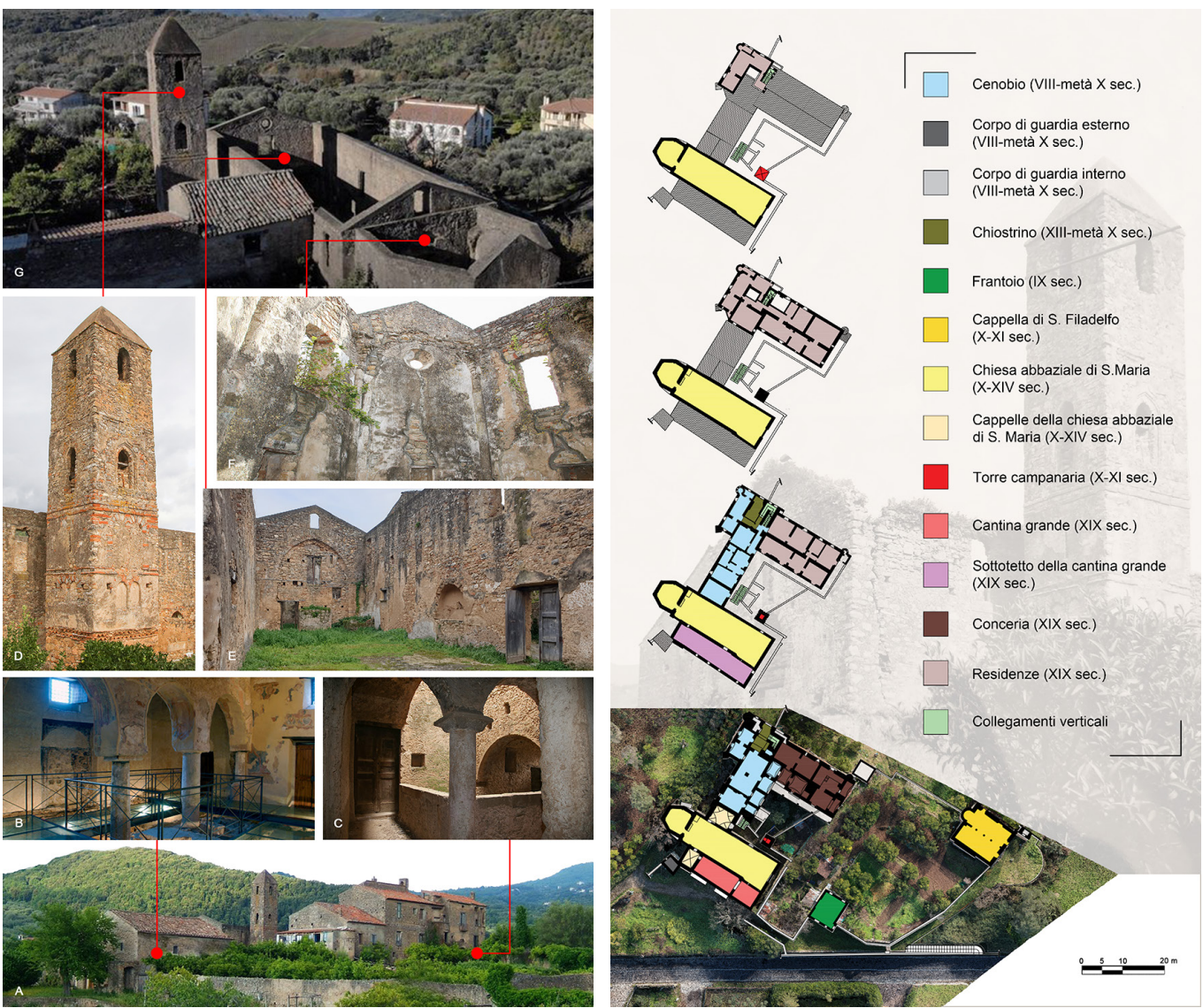

"from commandery to commandery, becoming increasingly degraded" [6]. Over the centuries, in fact, several functional volumes were added to the original structure to meet the needs of the new conductors. Some examples are the long body of the building leaning against the left side of the church and the building used as a laboratory for tanning skins and as a dwelling erected perpendicularly to the original nucleus of the monastery (fig. 6). The difficulty of precisely dating the various artefacts and defining their functions over the centuries is confirmed by various authors [2]. 


\section{The knowledge of the site through the survey}

The monastic complex of Pattano, despite its considerable importance from a cultural and architectural point of view, is not sufficiently documented by published survey. The only works that represent, on an appropriate scale and with various views, the complexity of the building date back to about fifty years ago and are preserved in the historical archives of the Soprintendenza Archeologica, Belle Arti e Paesaggio for the provinces of Salerno and Avellino [3] (fig. 7).

Fig. 7. Extract of the table n. 4 - Prospetti del Progetto di Restauro de Campanile della Badia di Pattano (SABP-SA-AV).

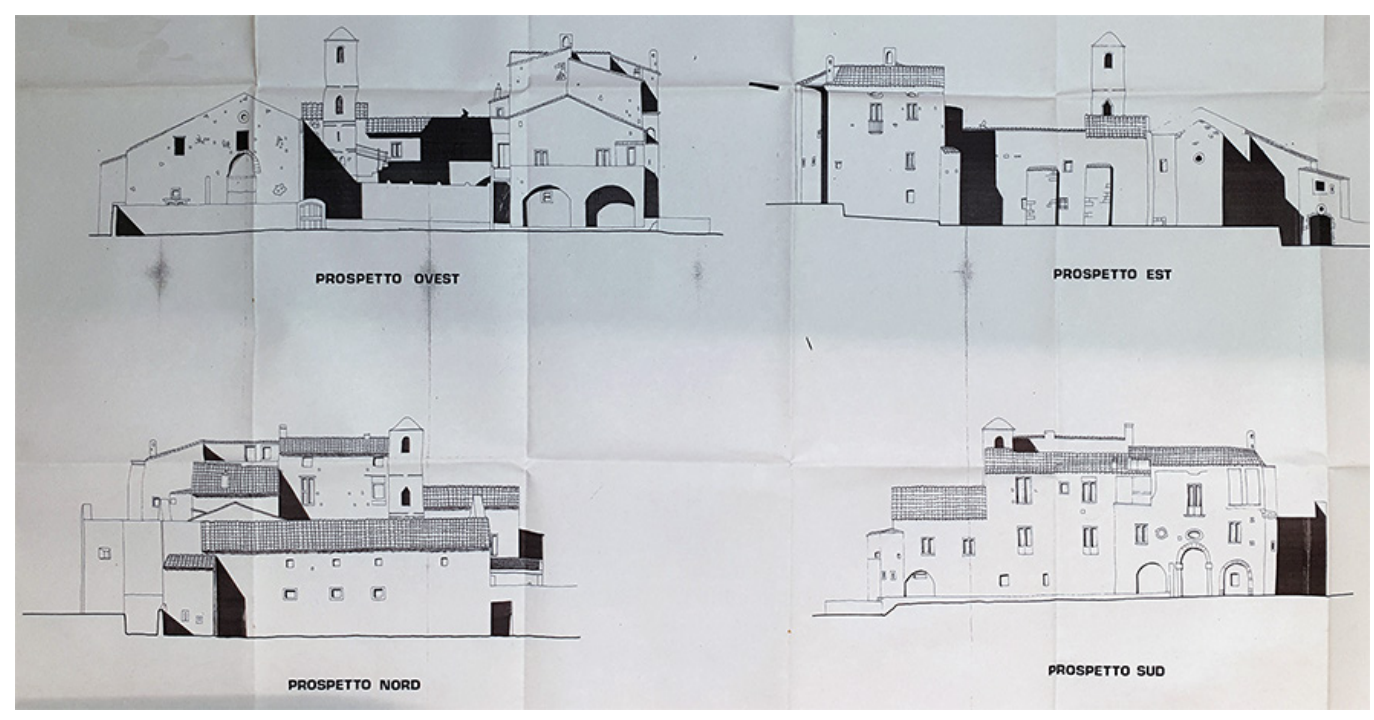

The contribution summarizes the ongoing research aimed at surveying the Badia and its context in a systematic way and by means of current technologies of three-dimensional and colorimetric digitization, for various reasons: to analyse the volumetric relationships between the various artefacts; to date in a coherent manner, thanks also to a precise reading of the masonry vestments, the construction phases that have affected the monastery; to virtualise the architecture for the purposes of scientific dissemination and cultural enhancement; to update and disseminate the surveys, with particular attention to details and surviving decorations; to identify typological aspects common to the many contemporary Cilento monasteries in order to draw up an atlas of the monastic construction techniques of the territory. Due to the state of many of the rooms in the Badia, it is not possible at present to carry out an in-door survey safely. Before timely and not too invasive maintenance and minimizing the risk of collapse (some floors and roofs should be propped up and several stone blocks relocated), an aerial photogrammetric survey was designed using a DJI Spark drone, in order to create a three-dimensional model for the first morphometric surveys of the complex.

The flight plans were designed taking into account the expected GSD (at least $2 \mathrm{~mm} / \mathrm{pix}$ for 1:50 scale representations), the technical characteristics of the photographic sensor (12 MPx with $1 / 2.3^{\prime \prime}$ CMOS sensor) and the desired overlap between consecutive sockets (at least 70\%) and were planned remotely on a web platform [4] automatically connected to the in situ flight management software application. As can be seen in figure 8 , six swaths were programmed: two at an altitude of 30 meters on the entire lot with nadiral camera (inclined at $85^{\circ}$ with respect to the horizon) and with orthogonal north-south and eastwest directions; four at an altitude of 20 meters on the built up area alone, alternately with nadiral and oblique camera (at about $45^{\circ}$ ) and with orthogonal directions (fig. 9). 
Fig. 8. Some flight projects with related settings.

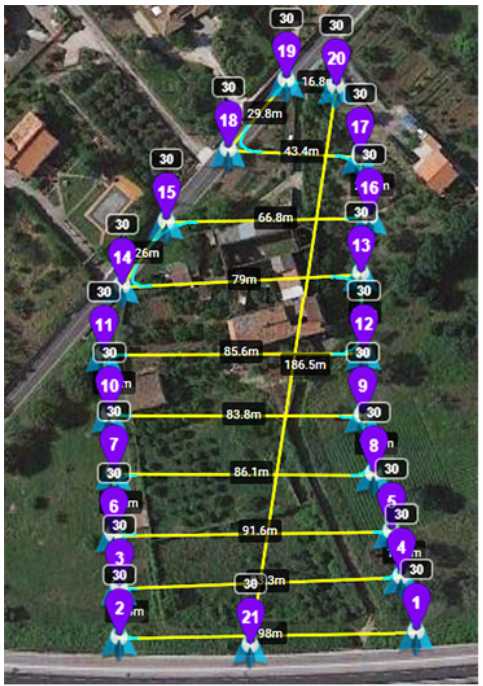

Settings

Units

Heading Mode

Finish Action

Path Mode

Cruising Speed

Max Flight Speed

Photo Capture Interval

Default Curve Size

Default Gimbal Pitch Mode

Show Discover Missions

Use Online Elevation

$$
\text { Settings }
$$

Units

Heading Mode

\begin{tabular}{l|l|l|l|}
\hline Auto (TNW) Initial (ID) & Manual (UC) & Custom (WD) \\
\hline
\end{tabular}

Finish Action

$$
\begin{array}{|l|l|l|l|l|}
\hline \text { None } & \text { RTH } & \text { Land } & \text { Backto } 1 & \text { Reverse } \\
\hline
\end{array}
$$

Path Mode

$$
\begin{array}{|l|l|}
\hline \text { Straight Lines } & \text { Curved Turns } \\
\hline
\end{array}
$$

Cruising Speed

Max Flight Speed

$$
10.0 \mathrm{~km} / \mathrm{h}
$$

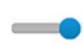

Photo Capture Interval

$$
10.0 \mathrm{~km} / \mathrm{h}
$$

Default Curve Size

1.0

\section{Seconds Meters}

\begin{tabular}{|l|l|l|l|}
\cline { 2 - 4 } Default Gimbal Pitch Mode & Disabled & Focus POI & Interpolate \\
\hline
\end{tabular}

Show Discover Missions

Use Online Elevation

\section{\begin{tabular}{|l|l|}
\hline Metric & Imperial \\
\hline
\end{tabular}}

\begin{tabular}{|l|l|l|l|}
\hline Auto(TNM) & Initial (ID) & Manual (UC) & Custom (WD) \\
\hline
\end{tabular}

\begin{tabular}{|l|l|l|l|l|}
\hline None & RTH & Land & Back to 1 & Reverse \\
\hline
\end{tabular}

\begin{tabular}{|l|l|}
\hline Straight Lines & Curved Turns \\
\hline
\end{tabular}
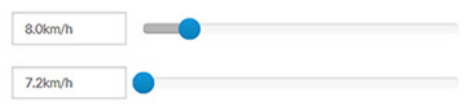

\begin{tabular}{|l|l|l|}
\hline 0.7 & Seconds & Meters \\
\hline
\end{tabular}

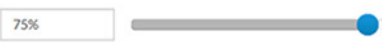

\begin{tabular}{|l|l|l|}
\hline Disabled & Focus POI & Interpolate \\
\hline
\end{tabular}

$\square$

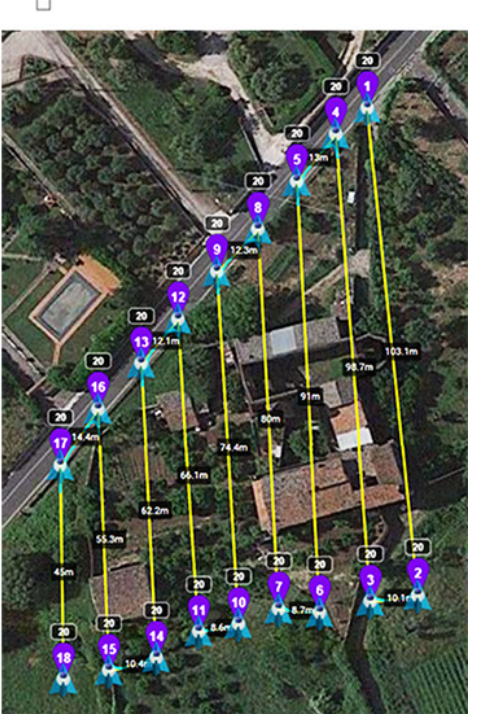

\begin{tabular}{|c|c|c|c|c|c|c|c|c|}
\hline VOLO & $\begin{array}{c}\text { TRAGITTO } \\
(\mathbf{m})\end{array}$ & $\begin{array}{c}\text { VELOCITÀ } \\
(\mathbf{K m} / \mathbf{h})\end{array}$ & $\begin{array}{c}\text { DURATA } \\
(\mathbf{m} \mathbf{i n} .)\end{array}$ & $\begin{array}{c}\text { QUOTA } \\
(\mathbf{m})\end{array}$ & DIREZIONE & $\begin{array}{c}\text { N. } \\
\text { STRISCIATE }\end{array}$ & $\begin{array}{c}\text { N. } \\
\text { SCATTI }\end{array}$ & $\begin{array}{c}\text { INCLINAZIONE } \\
\text { CAMERA }\end{array}$ \\
\hline 1 & 890 & 8 & 9 & 20 & est-ovest & 12 & 258 & $45^{\circ}$ \\
\hline 2 & 765 & 8 & 8 & 20 & nord-sud & 9 & 265 & $45^{\circ}$ \\
\hline 3 & 1125 & 10 & 9 & 30 & est-ovest & 10 & 169 & $85^{\circ}$ \\
\hline 4 & 610 & 7 & 7 & 20 & est-ovest & 10 & 249 & $45^{\circ}$ \\
\hline 5 & 576 & 6 & 8 & 20 & nord-sud & 10 & 306 & $42^{\circ}$ \\
\hline 6 & 1173 & 10 & 10 & 30 & nord-sud & 7 & 299 & $85^{\circ}$ \\
\hline
\end{tabular}


Fig. I0. A photo-modeling process.

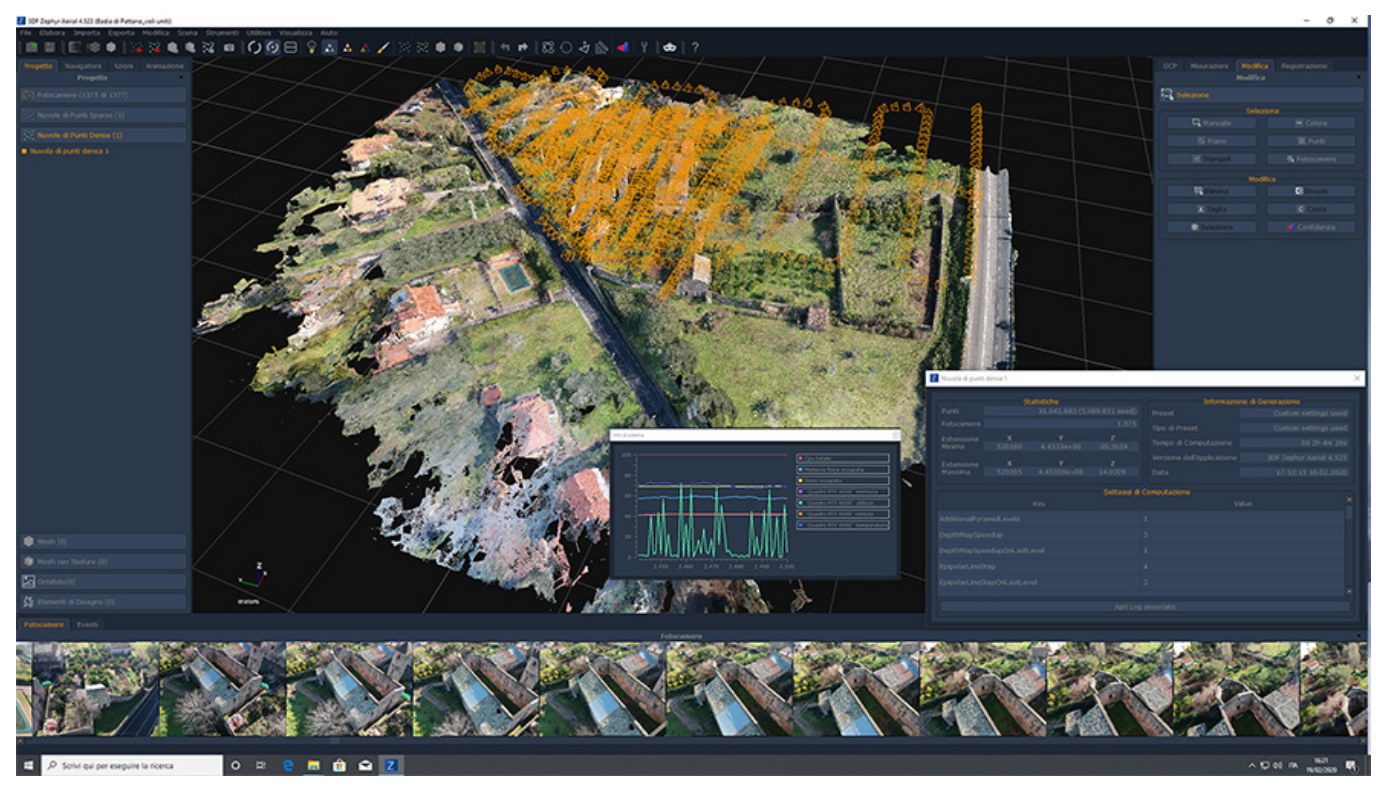

The acquired data (I 375 frames with as many GPS data) were then processed through a reliable photo-modelling software [5] that managed to align correctly and in absolutely acceptable times ( 2 hours and 4 minutes) all the sockets, georeferencing and scaling the point cloud model (about 3 I million points) with the coordinates acquired by the drone sensor (fig. 10). The latter, although it cannot be absolutely reliable as a professional GPS receiver, has nevertheless returned information deemed sufficient for the purposes of this survey. The model thus obtained constitutes the database for future graphic elaborations and will be integrated with laser-scanning clouds and total station points (fig I I).

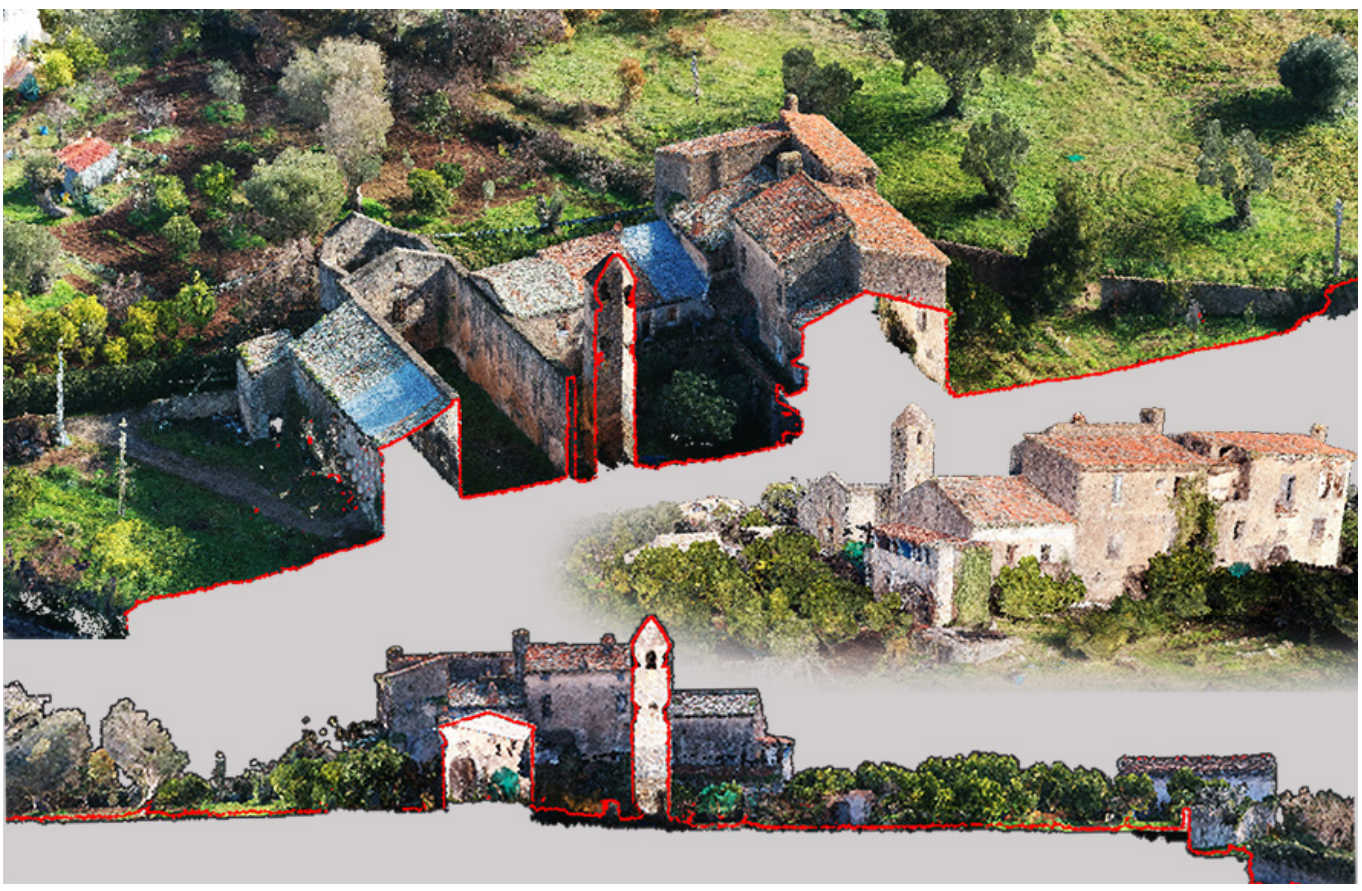




\section{Conclusion}

The research, although at an early stage of development, has highlighted how fundamental and productive the interdisciplinary approach to a theme is. The Badia of Pattano represents only one of the countless cases of invaluable historical and cultural evidence that has been forgotten and that needs to be enhanced through multiscale and broad-minded approaches. The internal survey of the artefacts that makes up the monastic complex and its subsequent representation is currently at the planning stage. In fact, wanting to introduce new and tangible strategies for the enhancement of heritage, it is essential to rely on a precise metric description to implement the information collected in information systems that allow interaction and usability at different levels. Through the contextual critical reading of the archive documents and the infographic models produced (point clouds, high-resolution orthophotos of the masonry vestments, plans, sections and elevations, architectural details) it will be possible to define a more reliable chronology of the structures to shed light on the history of the Badia and its relationship with the context (fig. I2).

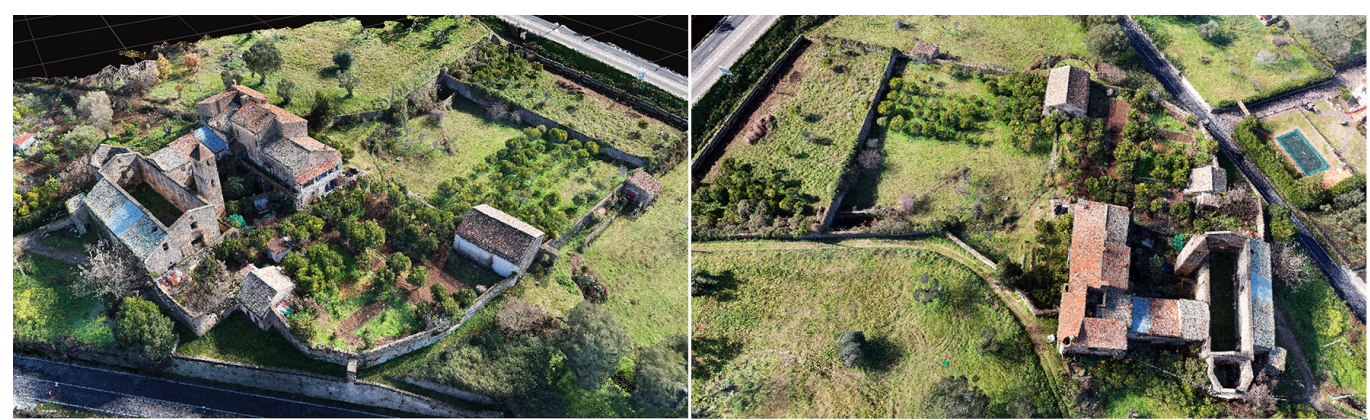

\section{Acknowledgement}

The authors thank Dr. Lara Giulio, councilor of the Municipality of Vallo della Lucania with powers to the Policies for the enhancement and requalification of the artistic and cultural heritage, and Dr. Elvira Cantarella, administrative officer of the Archaeological, Fine Arts and Landscape Superintendence for the Provinces of Salerno and Avellino.

\section{Notes}

[I] On the subject cf. Ebner 1979.

[2] De Giorgi ( 1 882), about the church of Santa Maria, writes that "fresh from the 17th century superimposed on other very ancient Greek style buildings barbarously mutilated for the new buildings leaning against the old ones". Again, Ebner (1967) states that "at present it is impossible to establish whether the abbey church was rebuilt (second half of the I3th - before the | 4th century) on the primitive or whether it should be seen in that of St. Philadelphus".

[3] The graphs are related to Survey of the monument before the reconstruction and restoration. Church of S. Filadelfo (f. F3-95 I); Restoration project of the church of S. Filadelfo, designer prof. arch. Arnaldo Venditti, 1990 (f. F3-954); Executive project. Recovery of the abbey complex of Santa Maria di Pattano and pre-diagnosis and degradation conditions, designers architects Gerardo Del Gaudio, Antonio Gambardella, Franco Luongo, Domenico Nicoletti, 1993 (f. F3-954): Restoration project Badia di Pattano. Restoration of the bell tower, designer prof, arch. Arnaldo Venditti, 1994 (f. F3-996); Consolidation and restoration work for the enhancement of the monumental complex of S. Maria de Pactano, various designers, 2004 (f. F3-1365); Restoration of the monumental complex of S. Maria di Pattano (Vallo della Lucania - SA), designer arch. Francesco Mautone (f. Z).

[4] www.flylitchi.com.

[5] 3DF Zephyr Aerial, versione 4.523. 


\section{References}

Cappelli Biagio (1957). Le chiese rupestri del materano. In Archivio storico per la Calabria e la Lucania, vol. 26, pp. 223-289.

Cerino Vincenzo (1997). La Badia di S. Maria di Pattano. Napoli: Zincografia Partenopea.

Comes Federica (20 I4). L'Architettura eremitica in Costiera Amalfitana. Specificità e problemi di conservazione. Tesi di Dottorato in Storia e conservazione dei beni architettonici e del paesaggio (XXVI Ciclo) Presso I'Università degli Studi di Napoli Federico II. Napoli.

De Giorgi Cosimo (20 I6). Viaggio nel Cilento. Casalvelino: Galzerano Editore. (Ed. orig. De Giorgi Cosimo (I 882). Da Salerno al Cilento. Firenze:Tipografia Galileiana).

De Luca Gaetano ( 1996). La badia di S. Maria di Pattano. In Natura e Montagna. Bologna: Pàtron Editore, vol. XLIII, pp. I-6.

De Magistris Ettore (199|). Problemi di Topografia del Litorale Velino. In Fra le Coste di Amalfi e Velia. Contributi di Storia antica e Archeologia. Napoli. Arte Tipografica, vol. 8, pp. 39-8I.

Ebner Pietro (1967). Monasteri bizantini nel Cilento. S. Maria di Pattano. In Rassegna storica Salernitana. Salerno: Società Salernitana di Storia Patria, 1968-1983, XXIX-XLIII. pp. I75-250.

Ebner Pietro (1979). Economia e società del Cilento medioevale. Roma: Edizioni di Storia e Letteratura.

Minucci Eleonora (2018). APR e droni nella moderna ricerca archeologica: un primo approccio. In Newsletter di Archeologia CISA, 9/2018, pp. $91-1 \mid 4$

Patrizio Salvatore (2003). Breve profilo storico del Cilento. In Rosi Massimo, Jannuzzi Ferdinando (a cura di). Le coste Napoletane Napoli: Officine Grafiche, pp. 233-248.

Repola Leopoldo, Giordano Andrea (2016). The double dynamics of knowledge: reality and virtual reality in the enhancement project of Torre Maggiore of Villa Rufolo, Ravello. In DisegnareCon, 17, 9, pp. I2. I - I2.9.

Venditti Arnaldo (1967). Architettura bizantina nell'Italia meridionale. Napoli: L'arte tipografica, vol. I-II.

Verhoeven Geert (2016). Basics of photography for cultural heritage imaging. In Stylianidis Efstratios, Remondino Fabio (eds.) 3D Recording, Documentation and Management of Cultural Heritage. Dunbeath Mill:Whittles Publishing.

\section{Authors}

Antonello Cerbone, Università degli Studi di Napoli Federico II, antonello.cerbone@unina.it

Saverio D'Auria, Università degli Studi di Napoli Federico II, saverio.dauria@unina.it

To cite this chapter. Cerbone Antonello, D'Auria Saverio (2020). Strategie per la valorizzazione di architetture monastiche. II caso della Badia di Pattano nel Cilento/The apulian pavilion at the Rome Exposition. Geographic and temporal connections in an ephemeral architecture. In Aren A., Arena M., Brandolino R.G., Colistra D., Ginex G., Mediati D., Nucifora S., Raffa P. (a cura di). Connettere. Un disegno per annodare e tessere. Att del $42^{\circ}$ Convegno Internazionale dei Docenti delle Discipline della Rappresentazione/Connecting. Drawing for weaving relationships. Proceedings of the 42th International Conference of Representation Disciplines Teachers. Milano: FrancoAngeli, pp. 1938 - 1957. 